\title{
A magyarországi bauxitok kutatásának rövid története (1903-2020)
}

\author{
MindSZENTY ANDREA
}

ELTE Általános és Alkalmazott FöldtaniTanszék

1117 Budapest, Pázmány Péter sétány 1/C. mindszenty@ caesar.elte.hu

\section{The short history of exploration for bauxite reserves in Hungary (1903-2020)}

Abstract

The history of exploration for and mining of domestic bauxite reserves in Hungary ended in 2013 when the Bakony Bauxite Ltd. closed down its last large-scale underground bauxite mine in Halimba. Scientific interest in bauxites has, however, survived and will hopefully continue also in the future. However, it will miss the field-information formerly always provided by the cores of exploratory boreholes and by the mining operations. The first research papers published on Hungarian bauxites are almost exactly coeval with the discovery of the Királyerdó bauxite in Transylvania (1903) and since then the study of various aspects of bauxites has never ceased. This paper gives a concise account of the most important events of the development of large-scale bauxite mining in Hungary and the results of geological research and exploration related to it.

The list of references includes all notable contributions published on the subject.

Keywords: bauxite reserves, history of exploration, Hungary

Összefoglalás

A hazai bauxitok bányászati célú kutatása a halimbai bauxitbánya 2013-ban bekövetkezett bezárásával - úgy túnik végérvényesen - lezárult. Tudományos tanulmányozásuk, amely szinte egyidős a 110 évet megélt ipari kutatással, remélhetőleg folytatódik, bár kétségtelen, hogy a bányászat s az azt megelőzô mélyfúrásos kutatás révén szinte naponta keletkező újdonságértékú feltárásokat ezentúl legfeljebb a mintaraktárakban megőrződött(?) anyagok fogják jól-rosszul helyettesíteni. A visszatekintés, az eddigi eredmények számbavétele mindenképp időszerú. Erre tesz kísérletet a cikk, amely a királyerdei bauxit 1903. évi felfedezésétől kezdve a Vértes, a Bakony a Villányi-hegység, majd végül a Gerecse bauxitkincsének kutatásán-feltárásán át az ipari és a tudományos igényú vizsgálatokig, a sokoldalú őslénytani, ásványtani, kőzettani, geokémiai felismerésekig s az ezek alapján megfogalmazódott paleogeográfiai, szerkezetföldtani, geodinamikai szintézisekig villantja fel a történet legfontosabb elemeit. Mindezek részletes kifejtésére természetesen a rövid áttekintés nem ad lehetőséget, a terjedelmes irodalomjegyzék segítségével azonban az érdeklődők kielégíthetik kíváncsiságukat.

Az irodalomjegyzék - a hivatkozott irodalmon túl - tartalmazza a témában megjelent mérvadó közleményeket.

Tárgyszavak: bauxit elófordulások, kitermeléstörténet, Magyarország

\section{A kutatás kezdetei és az elsố bányanyitások}

A tudománytörténet a bauxit felfedezését a 19. sz. elejére (1821) teszi és a nagy francia geológus-mineralógusvegyész, Pierre BERTHIER nevéhez köti. A feljegyzések szerint egy kis provence-i település, Le Baux közeléből származott az a minta, amelyet egy M. BLAVIER nevú ember azzal küldött be BERTHIER laboratóriumába, hogy a minta feltehetően vasérc. Erről a vöröses színú, agyagosnak tûnő mintáról állapította meg BERTHIER, hogy az ugyan valóban tartalmaz vasat is, de alumíniumban gazdagabb, mint vasban, s minden bizonnyal valamilyen ásványkeverék. Az anyagot a lelóhely neve után beauxit-nak nevezte el (mely név később módosult bauxittá). Tartozunk azonban az igazságnak azzal, hogy mindezt több mint 100 évvel megelőzte egy különös, piritesedett, majd elmállott, szürke bauxit bányászata és ipari hasznosítása anélkül, hogy a felhasználók sejtették volna a kibányászott anyag valódi természetét. Egy P. TURINI nevú mérnök 1808-ban Velencében publikált írásából tudjuk, hogy Isztrián a 16. sz. végétôl egészen 1857-ig 
Sovignacco (ma Sovinjak) település határában, a pirites bauxit alunitos málladékából készített timsót a környék bőrgyáraiban bőrcserző anyagként hasznosították. A történet részleteit a Földtani Közlöny 1997. évi kötetében, BÁRDOSSY György rendkívül olvasmányos cikkében tárgyalja. A már hivatalosan a 20. sz. emblematikus nyersanyagának, az alumínium ércének tekinthető bauxit bányászata azonban ténylegesen Franciaországban, a provence-i lelőhelyen indult meg az 1860-as években. A gyorsan fejlódó alumíniumipar érdeklődése azután Provence-tól csakhamar a kiterjedt francia gyarmatbirodalom trópusi területei (pl. Guinea) felé fordult, ahol a felszínt borító mállási takaróban már korábban, viszonylag könnyen hozzáférhetô helyzetben ugyancsak ércminôségú, alumíniumban dús anyagot találtak.

Magyarországon bauxitot elsôként, 1903-ban, az erdélyi Királyerdő vasérctelepeinek anyagában MiKó Béla kohófómérnök és FABINYI Rudolf kolozsvári egyetemi tanár vizsgálatai azonosítottak: az ott is, akkor is gyenge minőségú vasércnek gondolt, vöröses színú mintában, a kolozsvári laboratórium mindössze 4-9\%-nyi $\mathrm{SiO}_{2}$ mellett $50-55 \% \mathrm{Al}_{2} \mathrm{O}_{3}$ tartalmat elemzett. A leletról az első́ tudományos közlemény - SZÁDECZKY Gyula tollából - 1905-ben a Földtani Közlöny hasábjain látott napvilágot (SZÁDECZKY 1905). A későbbiekben - nyilván az ipari-gazdasági vonatkozások miatt többnyire inkább a Földtani Intézet Évi Jelentése köteteiben, valamint a Bányászati Lapokban és a Természettudományi Közlönyben találunk általában a bauxitra vonatkozó híradásokat. A termelés - kis volumenben - 1915-ben indult meg a Jád völgyében. A termelvényt Németországba exportálták (PoSGAY 1981). A világháborút lezáró, egész Magyarországra, s így az épp kibontakozni készülő magyar bauxitbányászatra nézve is sérelmes békeszerződést követően az új nyersanyag iránti hazai érdeklődés jobb híján a Dunántúli-középhegység, majd a Villányi-hegység felé kellett forduljon.

A kutatás csaknem egy időben - 1919-20-ban - a Bakonyban Halimbán és a Vértesben Gánton kezdôdött meg. Halimbán, illetve Halimba tágabb körzetében Zalatnai STÜRMER József és Aknaszlatinai GYörgY Albert; Gánton BALÁS Jenô volt a kezdeményezô. STÜRMER valójában kôszenet kezdett kutatni, így akadt rá a halimbai medence peremén egy kőszénkutató fúrásban, a Malom-árokban már 1908-ban felfedezett vörösagyagra, melyról - mint annyian mások - először ő is azt hitte, vasérccel van dolga. Bár az hamarosan kiderült, hogy a vörös színú anyagnak alumíniumtartalma is van, az érc gyenge minőségére való tekintettel a geológusok - Kormos Tivadar, TAEGER Henrik és VADÁsZ Elemér - az akkor már az érdeklódés fókuszában lévő gánti telep megnyitását szorgalmazták, amelyen BALÁs Jenő kezdeményezését követôen egyre intenzívebbé vált a kutatás.

BALÁs Jenő első gánti zártkutatmányának bejegyzési dátuma 1920 volt. A bihari bauxit kutatásában kezdetektől jeleskedő gyergyóremetei bányamérnök az I. világháborút követően jött át a románok által megszállt Erdélyből Csonka-Magyarországra. Itthon sok más neves geológussal és bányamérnökkel együtt fogott hozzá a maradék ország ásványi kincseinek felkutatásához. Különös konjunktúrahelyzetbe hozta ez az időszak a hazai földtani kutatást.
A bányáitól, nyersanyagtelepeitôl megfosztott országban létkérdés volt új telepek felfedezése és mielőbbi termelésbe vonása, hogy ezzel megteremtődjék az ipar újraszervezésének lehetősége. A Gánton és általában a magyarországi bauxittelepeken megindult feltáró kutatás ennek a konjunktúrahelyzetnek a sikertörténete.

1920-26 között - az akkori technológiai színvonalat figyelembe véve - varázslatos gyorsasággal jutott el a gánti telepek megkutatása a bányanyitásig. A TAEGER Henrik 1908-as földtani térképének adatain nyugvó részletező céltérképezés, a bagoly,hegyi kutatóvágat, kutatóaknák, kézi fúrások, BALÁs Jenô prospektori tapasztalatai, majd a kutatásirányításba bevont geológus professzor, TELEGDI ROTH Károly tudása és az általa végzett készletbecslés adta meg az alapot arra, hogy BORTNYÁK István bányamérnök kiválaszthassa a minőségét és települési viszonyait tekintve bányanyitásra legalkalmasabb teleprészeket. Meleges-Hosszúharasztos-Bagoly-hegy-Újfeltárás volt a sorrend. A termelés gyors felfutása egycsapásra a világ élvonalába emelte a trianoni Magyarországot. 1936-ra, évi 500000 tonnával, a világ 2. legnagyobb bauxittermelői lettünk. A feltárás beindításának költségeit fóként német (VAW), kisebb részben svájci (ALUSUISSE) tốkével rendelkező konzorcium (ALUÉRC Rt.) finanszírozta (1. ábra). Közben megkezdődött az Északi-Bakonyban Alsópere, a Déli-Bakonyban Halimba; ÉK felé haladva a Vértes-Gerecse területén Bicske Szár környékén az újbarok-óbaroki; majd Dél-Magyarországon, a Villányi rögökön a nagyharsányi telepek kutatása és feltárása is (I. táblázat és 2. ábra)

A II. világháború alatt a termelvény túlnyomó többsége a német hadiipar szükségleteit szolgálta. A háború végső szakaszában a bányaüzemek berendezéseinek többségét leszerelték, nyugatra szállították. A háború után, a potsdami egyezmény értelmében a bányák és a megmaradt létesítmények a győztes Szovjetunió tulajdonába kerültek. 1950 januárjában létrejött a MASZOBAL Rt., majd februárban a Bauxitkutató Expedíció. Gyakorlatilag innen számíthatjuk a szervezett, rendszeres bauxitkutatás kezdeteit.

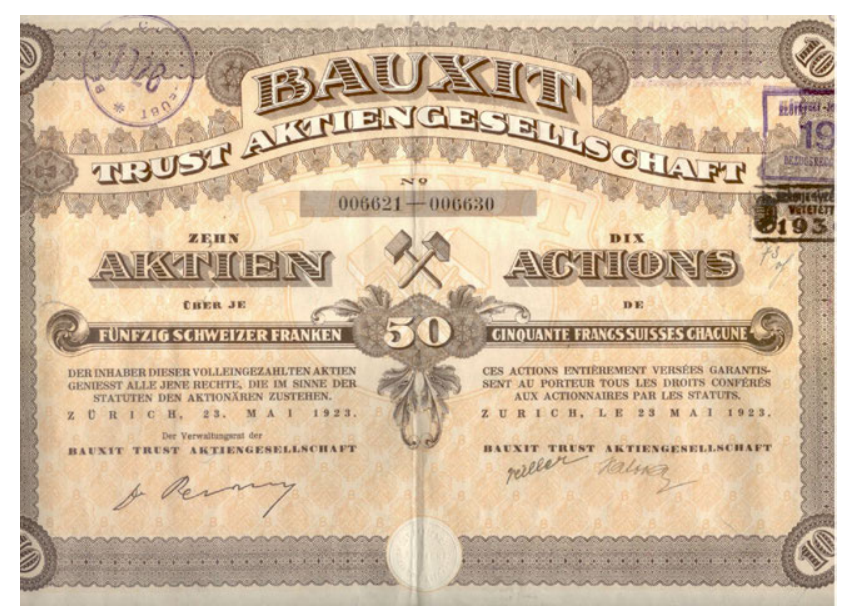

1. ábra. Egy 1923-ban a gánti bauxitbányászat pénzügyi hátterének megteremtése érdekében Zürichben kibocsátott részvény fakszimile másolata (Fodor B.) Figure 1. One of the shares issued in 1923 in Zürich in order to attract capital to finance the exploitation of the Gánt bauxite (courtesy B. Fodor) 
I. táblázat. A bauxitterületek kutatásának megindulása időrendi sorrendben Table I. Date of beginning of the exploration at major bauxite occurrences of Hungary

\begin{tabular}{|c|c|}
\hline A lelőhely neve & $\begin{array}{c}\text { Felfedezése } \\
\text { (a kutatás kezdete) }\end{array}$ \\
\hline Királyerdő (Erdély) & 1903 \\
\hline Gánt (Meleges, Hosszúharasztos, Bagoly-hegy) & 1920 \\
\hline Halimba-Malomárok & $1920(1908)$ \\
\hline $\begin{array}{l}\text { Halimba-(Cseres, II., III., } \\
\text { II-DNy*) }\end{array}$ & $\begin{array}{l}1943(1920) \\
(1993-1999)\end{array}$ \\
\hline Isztimér & 1922 \\
\hline Bakonyszentlászló & 1922 \\
\hline Nagynémetegyháza & 1922 \\
\hline Eplény & 1922,1925 \\
\hline Alsópere & 1926 \\
\hline Fenyőfő & 1927 \\
\hline Dudar & 1927 \\
\hline Piliscsaba & 1927 \\
\hline Nyirád (Deáki-h., Iza, Darvastó, Deáki stb.) & $1937(1928)$ \\
\hline Nagyharsány & 1930 \\
\hline Nézsa & 1935 \\
\hline Sümeg (Surgoth-tanya) & 1938 \\
\hline Szőc (Félix, Határvölgy, Nyíreskút stb.) & 1938 \\
\hline Óbarok-Vázsonypuszta & 1938 \\
\hline Iszkaszentgyörgy (Kincses, József, Bitó) & 1940 \\
\hline Nagyegyháza & $1940(1971)$ \\
\hline Szár & 1940 \\
\hline Kislőd & 1953 \\
\hline Fenyőfô & 1959 \\
\hline Csordakút & 1966 \\
\hline Csabpuszta & 1967 (1982) \\
\hline Iharkút-Németbánya & $1950(1990 *)$ \\
\hline Bakonyoszlop & $1968-(1999 *)$ \\
\hline Lengyelmajor & 1984 \\
\hline Csetény & 1985 \\
\hline $\begin{array}{l}\text { Óbarok-É és -DK, Szár } \\
\text { (Új kutatás) }\end{array}$ & $1987-(2000)$ \\
\hline
\end{tabular}

*Az új kutatások adatai JanKovics B., DiószEgi S. és TótH K. szerint.

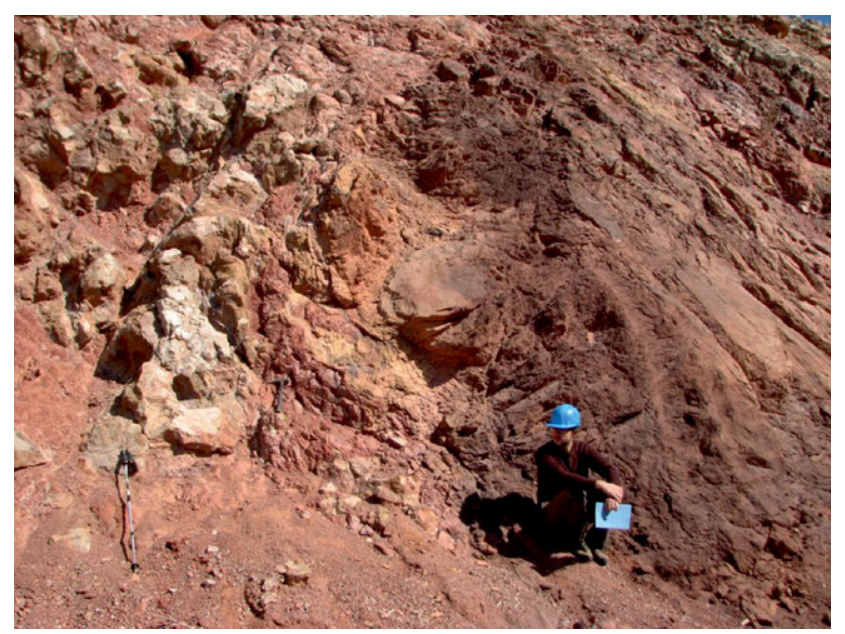

2. ábra. A kora-kréta (berriasi) Nagyharsányi Bauxitnak a szársomlyói kőbányában feltáródott részlete 2019-ben (a kép baloldalán a fekủ jura mészkő karsztos felszíne látható)

Figure 2. The Early Cretaceous (Berriasian) Nagyharsány Bauxite exposed by stone-quarrying on the Szársomlyó Hill, Villány (note the intensely karstified cliffs of the Late Jurassic bedrock on the left side of the photo

\section{A szervezett bauxitkutatás}

A szovjet nyersanyagkutatási rendszer - bár állítólagos merevsége miatt sokan, sokat kritizálták - voltaképp ma is, bárhol a világban megállja a helyét. Alapját - jól érzékelhetôen - a nyersanyagkutatás nagy öregjének, az angolszász H. E. MCKInSTRYnek az elvei képezik (McKinstRY 1961). Az elő-, felderítő, részletes és előzetes fázisokra tagolódó tevékenységet, a reménybeli készletmérleg éves karbantartását s számos más, ezekkel összefüggésben szükségessé váló kamerális munkát először a fent említett Bauxitkutató Expedíció, majd annak utódjaként 1954-tôl 1991-ig a Bauxitkutató Vállalat, ezt követően pedig, 1995-ig, a Geoprospect Kft. végezte. A szakmai (geológiai) irányítás 1957tôl folyamatosan SzANTNER Ferenc fógeológus kezében volt. Egymás után fedezték fel és kutatták meg a kislődi, nyirádi, halimbai, Iszkaszentgyörgy környéki, fenyőfői, bakonyoszlopi, a 70-es évektôl az iharkúti és németbányai, majd a 80-as években a Nagyegyháza-Csordakút-Mány környéki valamint a Nyirád csabpusztai kettős bauxitszintú területet. A kutatási tevékenység spektruma a '80-as évek végéig állandóan bővült. A 70-es évekre Balatonalmádiban, a „főhhadiszálláson” már önálló Kutatás-elókészítési (vezetôje KNAUER József), Kutatási (vezetôje KÁROLY Gyula, helyettese BAROss Gábor), Hidrogeológiai (vezetője HôRISZT György), Geofizikai (vezetője NYERGEs Lajos) és Kamerális Osztály (Szabó Elemér, Komlóssy György és R. SzABó István), valamint jelentős szellemi kapacitást foglalkoztató és - ifj. Dr. DuDICH Endre laborszervezô tevékenységének köszönhetôen - nemzetközi színvonalú és felszereltségú anyagvizsgáló laboratórium múködött (HoRvÁTH István, SzeKÉR Zoltán, Tóth Kálmán, Knauerné Gellai Mária, Tóthné GeCse Éva, Selényiné Szomjas Eszter és mások). Felfejlődött a fúrógéppark és általában a múszaki háttér is (ebben jelentôs része volt MeCSNóBER Miklósnak és SzAKÁLY Áronnak, valamint közvetlen munkatársaiknak és a mindenkori igazgatóknak, akik közül kiemelendő 19631971 között Vizy Béla, ill. 1986-1995 között, a végső szakaszban, TóTH Béla tevékenysége). A kezdeti, részben kézzel múködtetett Craelius gépeket 1960-62-ben a szovjet ZIF-ek, majd a '70-es években korszerú, köteles magvevővel, dupla falú magcsövekkel ellátott Wirth berendezések váltották fel. A kezdetben gépenként 10-11 főt foglalkoztató fúrási üzem a Wirth-korszak jelentôs részben automatizált gépei mellé már gépenként mindössze 2 fős személyzetet igényelt. Ráadásul ugrásszerúen megnőtt a fúrási kapacitás: az 1950-59 közötti 298900 fm-rel szemben 1960-76 között 1236100 fm. 1977-1990 között már összesen 1802000 fm volt. A géppark karbantartása, sőt a Wirth céggel kötött szerződés értelmében végül egyes fődarabok készítése, valamint teljes fúrógépek összeszerelése is a Kutató Vállalat saját múhelyében folyt. A terepi fúrócsoportok (Nyirád, Iszkaszentgyörgy, Farkasgyepú, Bakonyoszlop, Nagyegyháza) számára korszerú „fóhadiszállások” létesültek, amelyek a korra jellemző telefonos, majd telexes, később állandó rádiótelefonos összeköttetésben voltak a Balatonalmádiba telepített központtal. 
Mivel a külszíni kibúvásokon indult kutatások nyomán megismert területek készletei fokozatosan csökkentek, egyre újabb, de már nehezebben megtalálható telepek után kellett nézni. Ehhez új, komplexebb és az eddig megismert telepek tudományos tanulmányozásának eredményeire is támaszkodó kutatási módszereket kellett bevetni. A mélyfúrások optimális telepítése érdekében az alapos geológiai elókészítés mellé felzárkóztak a különféle geofizikai módszerek. Ezek alkalmazását eleinte csak az Eötvös Loránd Geofizikai Intézettel (SzABADVÁRY László, KAKAS Kristóf, BODRI Gyula, FARKAS István) való együttmúködés tette lehetôvé (OTTLIK \& SzABADVÁRY 1969). Idôvel azonban már a Bauxitkutató Vállalat saját geofizikusai is érdemben járultak hozzá mind a módszerfejlesztéshez, mind pedig - elsósorban a fúrólyuk-geofizikai módszerek - kivitelezéséhez és a mérések értelmezéséhez (ennek szervezéséből és irányításából elsősorban NYERGES Lajos, URAY Szabolcs és BALOGH Iván vették ki részüket). 1960-1990 között összesen mintegy 3000000 fm kutatófúrás mélyült s ennek eredményeként a készletgyarapodás elérte a 170 milló tonnát. Az éves mélyfúrásos kutatási teljesítmény jellemzóen 100-120 ezer folyóméter körül volt, a bányák termelése pedig a 80-as évek végére elérte az évi 3 millió tonnát.

Mivel a termelésbe vonható készletek 70\%-a már a '60as évek második felére csak mélymúveléssel volt elérhető, ezért egyre nagyobb hangsúlyt kapott a hidrogeológia. A közvetlenül a karsztos feküvel érintkező, sokhelyütt törésekkel szabdalt telepek biztonságos, gépesített mélymúvelésú bányászata csak száraz környezetben látszott megvalósíthatónak. Ehhez ki kellett dolgozni az ún. aktív vízvédelmi eljárást. Ebben az ALUTERV-es ALLIQUANDER Endre, POHL Károly és BALKAY Bálint (AlliquANDER 1966; PoHL 1966, 1973; BALKAY1966), valamint a VITUKI szakemberei BöcKer Tivadar és ScHMIEder Antal (BöcKer 1965a, b, Böcker et al. 1986, SchMIEDER \& POHL 1971, GRUBER \& PAPP 1969) és mások - mellett a Bauxitkutató Vállalat Hidrogeológiai Osztályának vezetôje, HőrIsZT György vállalt fontos szerepet (HőRISZT 1971). A karsztvízszintet fúrt aknákba telepített búvárszivattyúkkal úgy süllyesztették le, hogy mire a bányamúveletek a telepet elérték, ott a kialakult depresszió következtében a környezet már száraz volt. A kiemelt vizet (1985-ben összesen már kb. $300 \mathrm{~m}^{3} / \mathrm{min}$ - csak a Nyirádimedencében pl. $70 \mathrm{~m}^{3} / \mathrm{min}$ !) a tágabb környék vízellátásába bekapcsolva enyhíteni tudták a bányászat miatt bekövetkezett víznívócsökkenés káros hatásait. Ami a káros hatásokat illeti: pontosan tudták, hogy a cél elérése érdekében hozzá kell nyúlniuk a statikus vízkészlethez, azaz világos volt előttük, hogy az ún. ,aktív vízvédelem" sikerének záloga az utánpótlódást meghaladó mértékú vízkivétel. A csúcsidőszakban ez a DKH egészére nézve mintegy $800 \mathrm{~m}^{3} / \mathrm{min}$-re rúgott. A víznívó-csökkenés átlagosan elérte a 40 m-t, de pl. Nyirádon és Iszkaszentgyörgy-Kincsesbányán meghaladta a 100 m-t is! (CSEPREgi 2007). A depresszió mértékének és időbeli alakulásának a tervezés követelményeit kielégítő kiszámolása az ismeretesség '60-as évekbeli szintjén (amikor rutinszerú számítógépes modellezésre sem volt még lehetőség) igen komoly szellemi erőfeszítést igényelt. A vízemelés szigorúan ellenőrzött körülmények között zajlott. A vállalkozás részleteit Alföldi L. és CSEPREGi A. (in ALFÖLDI \& KAPOLYI 2007) a bányászat szempontjait is szem előtt tartva utólag kimerítô részletességgel és tudományos igényességgel elemezték. A földtani felépítés (tektonizáltság foka, az egyes képződmények vízvezetőképessége, a beszivárgás/utánpótlódás) szerepét JocHÁNÉ EDELÉNYI Emőke (MÁFI) is részletesen vizsgálta (JochÁNÉ EDELÉNYI 1997, JoCHÁNÉ EDELÉNYI et al. 1996). Kiemelendő a vízszintsüllyesztés lokális és regionális hatásának ellenőrzésére, a VITUKI-val közösen megtervezett és telepített vízszintmegfigyelő kúthálózat létrehozása, a rendszeres hidrogeológiai adatgyújtés és az adatok tárolása. Ebben jelentős szerepe volt többek között KESSLER Hubertnek (pl. KESSLER 1954). Az iparág részérôl a vízszintsüllyesztésben és a kapcsolódó hidrogeológiai jelenségek nyomon követésében a '80-as években az ALUTERV FKI (BöcKER Tivadar és ,„csapata”), a BKV-tól HőriszT György és HEGEDÛsné KonCZ Margit, a bányavállalatok részéról FARKAS Sándorné vállalt fontos feladatokat (BÖCKER \& HôRISZT 1992, FARKASNÉ 1992). (3. ábra). Megjegyzendő, hogy az ALUTERV-es POHL Károly és munkatársai a tervezési fázisban azt is előre kiszámolták, hogy a bányászati múveletek befejeztével megszúnó vízkivételt követôen mennyi idő alatt fog kisimulni a létrehozott depresszió (PoHL 1973). Ezt 1990 után JOCHÁNÉ EDELÉNYI Emőke elemzései is visszaigazolták!

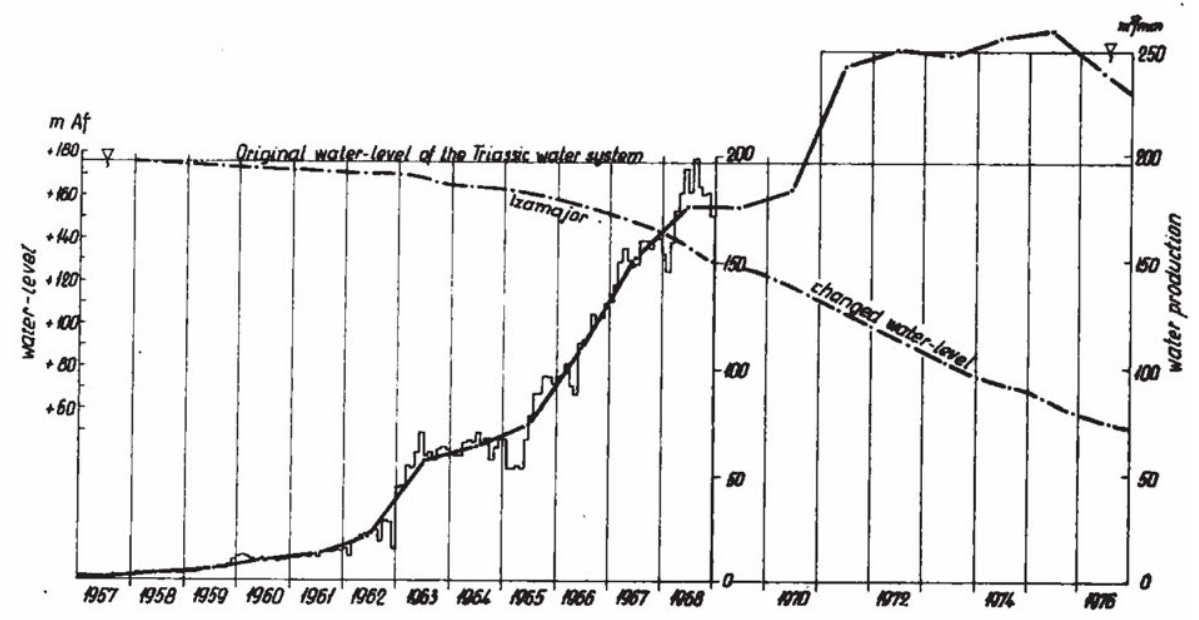

3. ábra. A bányászati célú vízemelés mértékének hatása a karsztvízszint alakulására 1957-1976 között nyirádizamajori adatok alapján HőRIszT Gy. 1969 szerint. (Bal oldalt a függőleges tengelyen a vízszintadatok (mAf); Jobb oldalt a vízemelés $\left(\mathrm{m}^{3} /\right.$ perc); folytonos vonal: a vízemelés mértékének időbeli alakulása; eredményvonal: vízszintváltozás az izamajori megfigyelőkútban)

Figure 3. The effect of active water-protection as obsereved in the Nyirád Izamajor bauxite-mining area (numbers on the left: vertical axis of the diagram show the elevation of the water-table ( $m$ asl), on the right the pumping rate $\left(\mathrm{m}^{3} / \mathrm{min}\right)$, continuous line: change of water-production with time, dotted line: change of the elevation of the water-table) 


\section{A recesszió}

A bauxitbányászat sikertörténetének végül az egyre inkább környezettudatos gazdálkodás szükségessége vetett véget: a '90-es évek elejétől gyakorlatilag megszűnt a karsztvízszint alatti bányászkodás. Kivételt Halimba-II. DNy és a fenyőfői előfordulás egy része élvezett, ahol a geológiai viszonyok biztosították, hogy a felszín alatti múveleteknek regionális hatása nem lesz. Minden egyéb kutatási és termelési aktivitást a külfejtésre alkalmas készletekre kellett összpontosítani. Így került sor a '90-es években Halimba-Nyirád térségében néhány, korábban mélymúveléssel termelt sekély teleprész (Táncsics, József, Ferenc) külszínről való újranyitására (I. tábla $B$ ): (a pillérben otthagyott anyag letermelésére); az Óbarok XI. és III. lencsék, valamint a Magas-Bakonyban az iharkúti területen a még külfejthető telepek (Németbánya II., III. lencsék) feltárására. Erre az időszakra már a hazai alumíniumipar egyértelmú recessziója nyomta rá a bélyegét. A kutatási tevékenység egyre inkább beszúküult, a minimumra korlátozódott. Az 1991ben Geoprospect Kft.-vé alakult, majd 1995-ben teljesen megszűnt, önálló kutatóvállalat szerepét a Bakonyi Bauxitbánya Kft. vette át, ahol a korábbi BKV kiemelkedő szakemberei (BöRÖCZKY Tamás, R. SzABó István, RAUsch Péter, MÁTÉFI Tibor) a Bakonyi Bauxitbánya Kft. tapasztalt bányageológusaival (Tiszay János, PATAKi Attila, JANKOvics Bálint, NovÁK Sándor, FeKETE István, DiószEGI Sándor) együtt 2003-ig a kft.-n belül önálló kutatási osztályként végezték mind a külszíni, mind a bányabeli kutatásokat. 2004-ben a külszíni kutatással foglalkozó néhány szakembert kiszervezték a bányától. Ettől kezdve a - PATAKI Attila vezetésével múködő - GeoÁsz Kft.-re hárult a még szükséges hazai és a minőségi követelmények miatt bekapcsolt - boszniai (Jajce környéki) telepek megkutatása is. A vértesi kutatások „hattyúdala” a '70-es évek végén elkészült ún. sekélykutatási program volt, amely részletező geomorfológiai céltérképezést követően erôs felszíni geofizikai támogatottságú sekélyfúrási tevékenységet irányzott elő a Gánt falutól ÉNyra eső Pátrácos és a Vértes-plató területén. Ezt a programot azonban végül is az iparág már nem hajtotta végre.

1988-ban az 1926 óta összesen 13,5 millió tonna bauxitot adó gánti terület utolsó külfejtése, a Bagoly-hegy is végleg bezárt. A kötelező rekultiváció keretében Bagoly-hegyen Bauxitföldtani Park létesült. A park tanösvényének terveit az egykori Bauxitkutató Vállalat geológusai, KNAUER József és KNAUERnÉ GELlai Mária készítették el. A kivitelező a Bakonyi Bauxitbánya volt. A bemutató terület voltaképp az 1976-ban létesített, de azóta az enyészeté lett melegesi tanösvény utóda, és jól illeszkedik a hosszú időn keresztül az Országos Bányászati Múzeum által üzemeltetett Bagoly-hegyi Bányászati Múzeumhoz, amely méltó emléket állít nemcsak a gánti, hanem az egész hazai bauxitbányászatnak, valamint az azt annak idején előkészítő és sikeresen szolgáló bauxitkutatásnak. A múzeum és a Bauxitföldtani Park kezelését néhány éve átvette és azt a hagyományok dicséretes ápolásának jegyében megórizni, valamint a lehetőségek adta keretek közt fejleszteni igyekszik Gánt község önkormányzata. A 1926-ban kezdődött bauxitbányászat végére 2013-ban Halimba-II. DNy bezárásával került pont ezzel lényegében megszúnt a hazai nyersanyagbázisra támaszkodó vertikálisan integrált alumíniumipar is. Hogy a megkutatott, de ki nem termelt bauxitkincset fogják-e még valaha valamire (pl. esetleg ritkaföldfémek kinyerésére) hasznosítani, az a jövố titka marad.

\section{A bauxitkutatással kapcsolatos tudományos eredmények rövid összefoglalása}

A tudományos és a nyersanyag-kutatási célú tevékenység egymásra utaltsága és - mindkét terület számára - gyümölcsöző kölcsönhatása jól tükröződik a bauxittal kapcsolatos hazai tudományos eredményekben és azok ipari hasznosulásában. A kutatófúrások mélyítése és a bányászati múveletek során keletkező adatok, valamint a nyersanyagtelepek felszíni és felszín alatti feltárásokban vizsgálható jellegei a tudomány számára kiváló lehetőséget kínáltak a szóban forgó nyersanyag genetikájának, korának, valamint számos - a feldolgozóipar szempontjából is lényeges - technológiai tulajdonságának megismerésére és pontosítására. Ugyanakkor a tudományos tanulmányozás eredményei fontosnak bizonyultak az ipari kutatás, valamint a megtalált telepek kitermelésére irányuló bányászati múveletek tervezéséhez/irányításához, továbbá elengedhetetlenül szükségesek voltak a kutatások szempontjából távlatilag reménybelinek minősülő területek körvonalazásához (nyersanyagprognózis). Ezt felismerve a magyar bauxitkutatás a kezdetektől gondot fordított a hazai tudományos múhelyekkel (egyetemekkel, kutatóintézetekkel) való együttmúködésre, és jelentôs anyagi forrásokat is mozgósított a nyersanyagkutatásban várhatóan hasznosuló alapkutatások finanszírozására. Mi több, számos alapkutatási témát a Bauxitkutató Vállalat (BKV) alkalmazott kutatásra szakosodott saját laboratóriumaiban, illetve terepi kutatócsoportjainál dolgozó szakemberek (pl. KoMLóssy György, VöRÖs István, DuDICH Endre, T. Gecse Éva, Knauerné Gellai Mária, Tóth Kálmán, TóTH Álmos, SzABó Elemér, SzANTNER Ferenc és mások is) megoldottak, s eredményeiket a szakterület hazai és külföldi kiadványaiban közkinccsé tették. Nevezetes - a Földtani Közlöny hasábjain megjelent - közlemények voltak: VADÁSZ 1943, 1966; VÖRÖS 1958; SZANTNER \& Szabó 1962; Komlóssy 1967; Dudich \& KomlósSY 1969, de kiemelendő BALKAY Bálintnak a Bányászati Lapokban közölt áttekintő értekezése is (BALKAY 1966).

\section{Az elsóként megismert gánti bauxit tudományos tanulmányozásának eredményei}

A gánti bauxittelep (4. ábra) faunagazdag fedőrétegsora („fornai rétegek”) már a 19. század fordulóján felkeltette a kutatók érdeklődését. Nem kisebb tekintélyú szakemberek foglalkoztak vele, mint a paleontológus HANTKEN Miksa (1861), PAPP Károly (1897), a térképező geológus TAEGER Henrik (1909) és a geológus professzor TELEGDI RoTH Ká- 


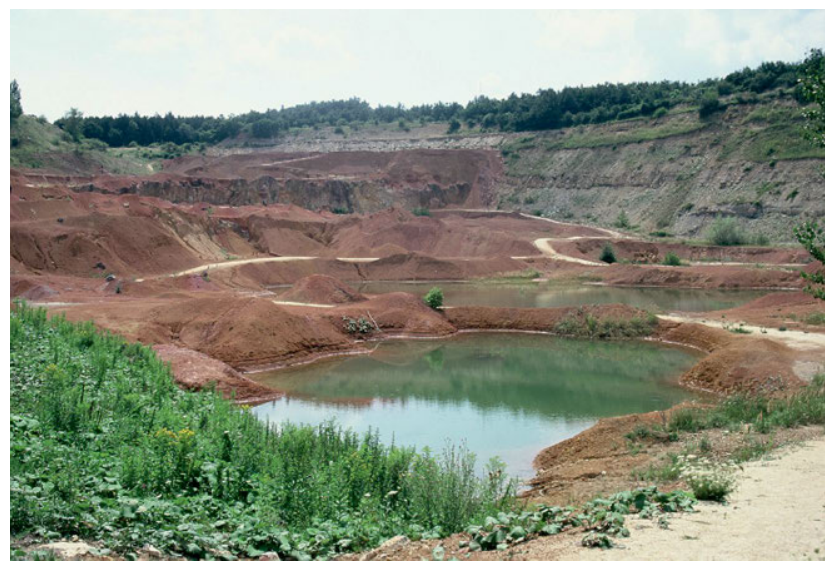

4. ábra. A Gánt bagoly-hegyi felhagyott külfejtés távlati képe (jobb oldalt a bauxitfedő késő-középső-eocén transzgressziós rétegsora látszik)

Figure 4. Panoramic view of the abandoned open-pit of Gánt Bagoly-hegy (yellowish scarp on top right is the late Mid-Eocene cover)

roly (1923). A bauxitteleprôl az elsô részletes tudományos leírást Telegdi RoTH közölte 1927-ben. A Bányászati és Kohászati Lapokban közzétett cikkében írja: „Alig néhány éve jutottunk azon nagy nemzeti kincs megismerésére, melylyel Csonkamagyarország a dunántúli bauxittelepekben rendelkezik és immár kivitelünk jelentôs tétele a gánti bauxit..." TELEGDI RoTH közleményét követték VADÁsz (1927), PoBOzSny (1928), DitTLER (1930), VitÁlis (1931), GEDEON (1932) munkái, majd a II. világháború után - egyebek mellett - VAdÁSZ (1946), J.G. DE WeISSE (1948), KISS (1955), KOPEK et al. (1965), KISS \& VÖRÖS (1965), BÁRDOSSY (1961), SZANTNER \& SZABÓ (1969), VöRÖS (1969) dolgozatai. A gánti bauxit keletkezésével kapcsolatban számos egymásnak ellentmondó elmélet látott napvilágot, míg végül a '80-as évek második felére, nem utolsóorban (akkor) fiatal kutatók (VATAi 1988, MindSZENTY et al. 1989, GERMÁNHEINS 1994) vizsgálatai nyomán kialakult a ma általánosan elfogadott vélemény. Eszerint a gánti bauxit telepméretekben áthalmozott képződmény, mely végleges leülepedési helyére az eocén transzgressziót bevezető szerkezeti mozgások és a paleocén-eocén termális maximumot követő klímaromlás együttes hatásának köszönhető nagyarányú talajerózió eredményeként került. Szállítási mechanizmusként a mállásnak kitett szárazulati térszínen végbement, iszapos törmelékfolyást jelölték meg (MinDSZENTY et al. 1989 és SzARKA A. egykori doktorandusz kéziratai)

Bár a gánti Bagoly-hegy (5. ábra) a hazai eocén litosztratigráfiai beosztás szerinti Gánti Bauxit Formáció típuslelőhelyeként van számon tartva, üledékföldtani sajátosságait tekintve alapvetően különbözik a legtöbb, ugyancsak a Gánti Bauxit Formációba sorolt hazai eocén bauxitteleptől. Felépítését alapvetően kétféle litológiájú (pelitomorf és bauxitkavicsos) kifejlődés meglehetősen kaotikus váltakozása uralja: a világosvörös, pelitomorf bauxitba sárgás-sárgásvörös, szabálytalan, hullámos rétegfelszínú, laterálisan gyakran szétseprûződő, szubhorizontális konglomerátum közbetelepülések ágyazódnak. A konglomerátum nagy része osztályozatlan, a szemnagyság gyerekfej nagyságú

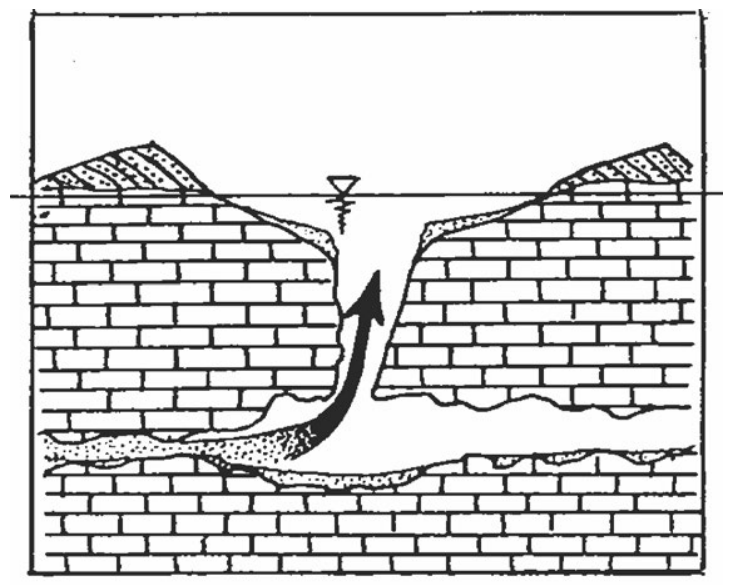

5. ábra. A karsztjáratokon keresztül alulról érkező „blue-hole”-típusú transzgresszió sematikus képe.

Figure 5. Cartoon showing the concept of transgression, from below" (the rise of the water-table is realized through the karstic channelways of the bedrock)

hömpölyöktôl 0,5 cm-ig változik. A kavicsok/gömbszemcsék (nem pizoidok!) belseje általában barna, barnásvörös, és talajosodott szövetet mutat, felületüket porszerú, sárga, goethites bevonat borítja, ezért tûnik messzirôl minden kavicsos réteg sárgának. A bauxit mátrixának általánosan fakóvörös, sárga, fehér, szürke színárnyalatai, a vasmobilizációs képletek feltûnő gyakorisága hívta fel a figyelmet arra, hogy a gánti telep esetében a telepméretekben sötétvörös színú bauxitokkal szemben kevésbé oxidatív felhalmozódási (és korai diagenetikus) körülményeket kell feltételezni. Ennek nyomán alakult ki a bauxitok geokémiai fáciesének vadózus és szemivadózus/freatikus csoportokba sorolása, és fogalmazódott meg, hogy a bauxittelepek ásványtani/litológiai sajátosságai és a befogadó karsztmorfológia együttesen fontos őskörnyezetjelző szereppel bír (KOMLÓSSY 1967, Mindszenty 1989, D’ ARgEnio \& Mindszenty 1995). A bauxit és a dolomitfekü határán megjelenő, a többi hazai bauxittelepnél megszokotthoz képest vastagabb és azoktól eltérô textúrájú - jelen állapotában vasoxidos - kéreg részletes vizsgálata kiderítette, hogy az korai diagenetikus eredetû, kezdetben pirites volt, a sajátalakú piritkristályok utóbb, a késôi diagenezis/epigenezis során alakultak át hematitpszeudomorfózákká (GERMÁN-HEINS 1994).

A bauxit ásványtani összetétele - a többi hazai eocén bauxithoz hasonlóan - boehmites-gibbsites, goethites, hematitos, nyomokban diaszporral és klorittal (chamosit) (KISS 1955; BÁRDOSSY 1961, 1977; MiNDSZENTY et al. 1989) Fố agyagásványa a kaolinit. A mikromineralógiai frakcióban $(0,06-0,2 \mathrm{~mm})$ az ultrastabilok (rutil, turmalin, metamikt cirkon) mellett, szép, sajátalakú, vulkanogén cirkonszemcséket, valamint változatos magmás-metamorf ásványokat (disztén, szillimanit is!) és kőzettörmelék-darabkákat tartalmaz (VÖRÖS 1969, MINDSZENTY et al. 1991). A cirkonszemcsékből DuNKL (1992) fission track módszerrel eocén kort határozott, bizonyítva ezzel a bauxitfelhalmozódással egyidejú vulkáni tevékenységre utaló piroklaszt eredetú anyaghozzájárulást. Ezt pontosították a legújabb vizsgálatok, amelyek szerint a cirkonszemcsék kora 45-40,5 M 
év (lutetiai), és minden bizonnyal - közvetlenül vagy áthalmozva - a periadriai vulkanizmushoz köthetô tufaszórás emlékét őrzik (KELEMEN et al. 2020 in press).

A telep eltemetôdéstörténetének és a bauxittest fedő alatti elváltozásának alapos vizsgálata nyomán egy korábban már (pl. MuNTYÁN I. által is) észlelt, de részleteiben nem magyarázott különleges transzgressziós jelenségre, az ingresszióra (VADÁsZ 1930, 1946; GEDEON 1932; KISS \& VÖRÖs 1965) és annak értelmezésére derült fény. Ingresszióról akkor beszélünk, amikor az erózióbázis közelében lévő, egyenetlen topográfiájú, sekélykarszt térszínen a transzgressziót bevezető fokozatos tengerszint-emelkedés egyre feljebb kényszerítve a karsztos járatokat kitöltő édesvizet, a korábbi dolinák/uvalák/poljék területén édesvízi tavacskák, mocsarak képződését eredményezi. E tavacskákban Characea-termésekben és édesvízi csigákban (Brotia distincta) gazdag, helyenként kôszenes agyag betelepülésekkel váltakozó, meszes üledék (édesvízi mészkő/márga) halmozódik fel (6. ábra), amelyet az alulról érkező transzgresszió előrehaladtával elôször brakk, majd schizohalin, végül - amint az előrenyomuló tenger már a karsztos domborzat által képviselt akadályokat legyőzve felülről is eléri a területet - normál tengeri üledékek váltanak fel. A rétegsor jellegzetességeit VADÁsztól SzŐTs Endrén keresztül BIGNOT et al.-ig, a gánti eocénnel foglalkozó paleontológusok a legnagyobb részletességgel dokumentálták (VADÁsz 1946, SzŐTS 1953, BIGNOT et al. 1985). Arra azonban csak a '90-es-es évek elején irányult rá a figyelem (CARANNANTE et al. 2004), hogy ez a transzgressziós rétegsor leginkább a Bahama-szigetekről ismert „,blue-hole” típusú transzgressziós rétegsorokhoz hasonlít, s azt jelzi, hogy a jól fejlett karsztjáratokon keresztül a transzgresszió Gánton is alulról érkezett (5. ábra). Az így megemelkedett karsztvízszint végül a bauxittal kitöltött töbrök elmocsarasodását, kőszenes agyag képződését eredményezte (PÁLFALVI 2007, MindsZENTy 2010). A Characeae-specialista Khaled TRABELSI és munkatársai legutóbbi vizsgálatai megerôsí-

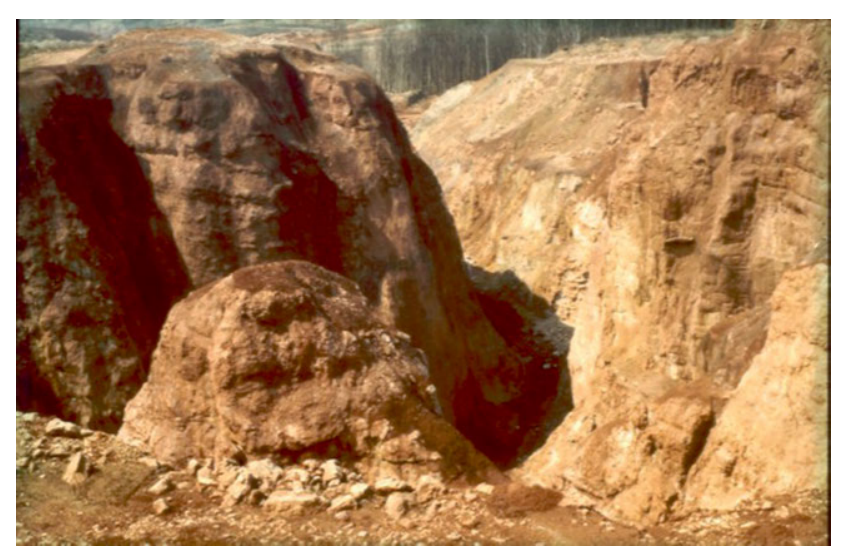

6. ábra. A Fődolomit Formáció felszínének a Németbánya-XI. lencse kréta időszaki bauxitjának letermelését követően feltáródott karsztos formakincse

Figure 6. Paleokarst morphology developed on the surface of the Triassic bedrock exposed by mining activity in the open-pit of Németbánya-XI. (Late Cretaceous bauxite, Iharkút) teni látszanak, valamint árnyalják és rétegtanilag pontosítják az eddigi elképzeléseket (TRABELSI et al. 2020 in prep.). Jól beleillik a képbe a telep alján kifejlődött, eredetileg pirites vaskéreg is. A piritképződéshez szükséges kén-tartalom ily módon jelentős részben az üledék pórusait kitöltô, a transzgresszió előrehaladtával már részben tengeri ( $\mathrm{SO}_{4}$-ionokat is tartalmazó, brakk) pórusvízből származtatható. Az áthalmozott bauxit alá beszorult növényi anyagot lebontó anaerob mikrobák indíthatták be a szulfátredukciót, s így a piritképződést (GERMÁN-HEIns 1994).

A gánti telepet átszelő, részben szinszediment, részben utólagos törések (I. tábla C) tanulmányozása (ALMÁsI 1993, FODOR 2007) ugyancsak érdekes új eredményeket hozott. A bagoly-hegyi külfejtésben feltáródott egy klasszikus, ún. váltórámpa (,,relay ramp”) amely a kulisszaszerúen elrendeződő, uralkodóan jobbos oldaleltolódások közötti kapcsolatot teremti meg. E törések elemzése derítette ki, hogy a mozgások már a fedô rétegsor lerakódását megelőzően elkezdődtek. Feltehetően az ezekkel együtt járó szeizmikus tevékenység indíthatta el a bauxit nagyarányú áthalmozódását is. Ugyanezen törések mentén azután később több ütemben újabb mozgások mentek végbe - a legfiatalabbak már az eocén rétegsor kőzetté válását követően, az oligocén/miocén folyamán (MINDSZENTY \& FODOR 2002).

A gánti bauxittelep tehát PAPP (1897) munkájától napjainkig hazai és külországbeli geológusok generációi számára vetett fel tudományos kérdéseket. A paleontológiától az ásványtanon, kőzettanon, geokémián, szedimentológián és paleotalajtanon keresztül egészen a szerkezetföldtanig a geológia csaknem minden tudományterületén jelentôs eredményeket hozott, és a vele foglalkozó kutatókat hozzásegítette a bauxitgenetika kérdéseinek jobb megértéséhez.

A teleprôl kialakított képet mutatja be-igényes rajzos és fényképes magyarázó táblákon - a KNAUER József és KNAUERNÉ GELLAI Mária által a '90-es évek elején megtervezett és fentebb már említett bagoly-hegyi „Bauxitföldtani Park”. A létesítés során a generálkivitelező Bakonyi Bauxitbánya Kft.-t hathatósan támogatta az Országos Természetvédelmi Hivatal, a Vértesi Tájvédelmi Körzet, valamint Gánt önkormányzata is. A Bauxitföldtani Park elődje a Melegesi- és Angerréti-külfejtések bezárását követôen a bányavállalat által a bauxitbányászat 50. évfordulójára létesített magyarázótábla-sorozat volt, amely azonban a '90-es évekre elpusztult. A Park még jelenlegi, meglehetősen leromlott állapotában is jól kiegészíti a Bagolyhegyi-külfejtés északi csücskében található (eredetileg a soproni Országos Bányászati Múzeumhoz tartozott) Bányamúzeumot. A két látnivaló közkedvelt úti célja a földrajz témájú iskolai kirándulásoknak, és számos egyéni turista számára is maradandó élményt nyújtanak. Újabban Gánt község önkormányzata (SPergelné RÁdl Ibolya polgármester, Mécs Csaba és társaik, valamint a község díszpolgára, dr. PATAKI Attila),,fogadta örökbe" a bemutató-helyet, és tervezik a tanösvény felújítását. Első lépésként a területet bekerítették, megkezdődött a túlburjánzó vegetáció gyérítése, felépült egy minden igényt kielégítő, tájba illő fogadóépület, és tervbe vették a magyarázótáblák felújítását is. 


\section{A többi hazai lelóhely tudományos tanulmányozásának eredményei}

A Déli-és az Északi-Bakonyban Halimba-Nyirád, Iharkút (6. ábra), Fenyőfő, Iszkaszentgyörgy-Kincsesbánya, valamint a Gerecse hegység délkeleti előterében Óbarok-Újbarok (I. tábla D, E), Nagyegyháza-Csordakút-Mány térségében az 1940-42-ben felfedezett, majd 1971-től intenzíven kutatott bauxittelepek tanulmányozása ugyancsak jelentôs előrelépést jelentett e területek mezozoos/tercier fejlődéstörténetének megismerésében, és hozzájárult a bauxittelepek feltárására irányuló ipari kutatási tevékenység optimalizálásához.

VAdÁsz (1927, 1946), J. G. de WeISSE (1948), majd VADÁSZ (1951) általános bauxitföldtani ihletésú munkáit a bauxitfeküvel és -fedővel foglalkozó, elsősorban paleontológiai/biosztratigráfiai megközelítésú tanulmányok, valamint néhány korai szedimentológiai mú követték (SzŐTS 1956, KopeK et al. 1965, KÁroly et al. 1970, OrAVECZ \& VÉGHNÉ NEUBRANDT 1961, KoPEK 1980). Az ismeretek szaporodásával a tektonikának a bauxittelepek képződésében és utótörténetében betöltött szerepét elemző munkák is napvilágot láttak (ERDÉLYi 1965; SZANTNER \& SZABÓ 1962, 1969; DuDich \& KoMLóssy 1969). Magának a bauxitnak, mint üledékes kôzetnek, részletes tudományos tanulmányozása BÁRDOSSY György vizsgálataival indult, melyeket A magyar bauxit geokémiai vizsgálata c. monográfiájában foglalt össze (BÁRDOSSY 1961). Ezzel részben egyidejúleg, részben ezt követően jelentek meg KISS (1955), VöRÖS (1958, 1969), GECSE \& MindSZENTY (1968) mikromineralógiai vizsgálatainak eredményei, majd KoMLóssy György az iszkaszentgyörgyi bauxittal foglalkozó, számos új ásványgenetikai eredményt felmutató dolgozatai. KomLóssy kimutatta, hogy a hazai közfelfogással ellentétben a fekü karbonátos kőzetek a bauxittelepek képződésére alkalmas anyakôzetként (is) szolgálhattak (KoMLóssy 1967, 1970).

Az 1964-ben Zágrábban, magyar és horvát kezdeményezésre megalakult ICSOBA - a bauxit-timföld-alumínium tárgyú alap- és alkalmazott kutatásokat összefogó nemzetközi szervezet (International Commitee of Studies on Bauxite, Alumina and Aluminium) - jelentős lendületet adott a magyarországi bauxitok tudományos tanulmányozásának is. Sorra jelentek meg a legújabb rétegtani, ásványtani/geokémiai eredményeket s az azokra épülő szintéziseket bemutató cikkek (DuDich \& KÁroly 1964, KomLóssy 1970, VöRÖS 1969, VÖRÖS \& GECSE 1976, SZANTNER et al. 1981). DuDICH \& KoMLósSY (1969) a részeredményekból kiindulva már ekkor paleogeográfiai és szerkezeti szempontok alapján kísérelték meg a bauxitosodás és telepképződés korának pontosítását. Ebben az időszakban sokasodtak meg a közvetlenül a bányászathoz (annak elókészítéséhez) kapcsolódó, hidrogeológiai tárgyú elemzések (pl. HőRIszT 1969 és a fentebb már hivatkozott többi vízszintsüllyesztéssel foglalkozó tanulmány). Kiemelendő BALKAY Bálintnak az ICSOBA Travaux 1973. évi kötetében közzétett írása („Bauxitization and underground drainage" (BALKAY 1973), amelyben számos későbbi tudományos cikkben ismétlődően felbukkanó összefüggésre mutatott rá a bauxitosodás és a hidrogeológia között. Hazai és külföldi karsztbauxitos és lateritbauxitos példákkal illusztrálta, hogy a vízelvezetés mechanizmusának kulcsfontosságú szerepe van a mállási szelvényben, illetve a karsztos üledékcsapdákban felhalmozódó anyag bauxittá vagy csak túzálló (kaolinites) agyaggá alakulásában. A tudományos munkát illetően a Bauxitkutató Vállalat geológusai mindvégig élvezték a szakvezetés (a főgeológus SzANTNER Ferenc és az Anyagvizsgáló Laboratórium vezetôi, az alapító DuDICH Endre, majd HoRvÁTH István és SzEKÉR Zoltán) hathatós támogatását. Eredményeiket a Magyarhoni Földtani Társulat Közép- és Északdunántúli Területi Szervezetének, valamint az MTA Veszprémi Akadémiai Bizottságának szakülésein mutatták be, és a Földtani Közlönyben vagy a MÁFI Évi Jelentése köteteiben, valamint az ICSOBA Travaux folyóiratában tették közzé, ezzel is biztosítva az ipari bauxitkutatás révén keletkező új földtani ismeretek bekapcsolását a hazai és nemzetközi tudományos élet vérkeringésébe.

A közös kutatások eredményeként vált ismertté a bauxit közvetlen fekü- és fedőképződményeinek számos őslénytani, biosztratigráfiai és paleoökológiai sajátossága (ORAVECZ \&VÉGHné Neubrandt 1961, KÁroly et al. 1970, KopeK \& KeCSKEMÉTi 1965, VÉGHnÉ NeUBRANDT et al. 1978, CZABALAY 1983, KOMLÓSSY 1970, KNAUER \& KNAUERNÉ GELlaI 1978, HAAS 1979, TóTH 1981), amelyek később a közvetlen fedő fáciesének elemzése révén hasznos gyakorlati útmutatóul szolgáltak a részletes fázisú kutatófúrások optimális telepítéséhez. Kiemelendő a felszíni- és fúrólyuk-geofizikai mérések alkalmazásának a kutatás sikerességét kedvező irányban befolyásoló alkalmazása (SzABADVÁRY et al. 1978), valamint a sekélykutatási területeken (kiemelten Iharkút) bevetett felszíni geomorfológiai térképezés KNAUER József nevéhez füzôdő rutinszerû bevezetése. Ez utóbbi a bauxit és a befogadó kőzet vízvezető-képességének különbözőségén, valamint azon alapul, hogy a bauxit kompakciója folytán a bauxittal kitöltött töbrök felszíne mindig konkáv alakzatot mutat. Ha az eredeti fedőrétegek lepusztulása következtében a bauxitot másodlagosan csak mintegy 10 m-nél nem vastagabb laza üledék (lösz vagy homok) fedi, akkor ezen a laza fedőn átsejlik a bauxit felett kialakult morfológiai mélyedés, ráadásul a tálalakú mélyedésben (az alatta lévő bauxit rossz vízvezető-képessége miatt) nedvességkedvelő növényzet telepedik meg (lásd még SZANTNER \& MiNDSZENTY 1979). E jelek felismerése segítséget jelent a felszín közeli bauxittelepek felkutatását célzó geofizikai, majd az azt követő fúrási múveletek tervezésekor.

A Bauxitkutató Vállalatnál T. GECSE Éva által kidolgozott vékonycsiszolatos bauxit-petrográfiai-szedimentológiai vizsgálati módszereknek a MÁFI (JuHÁsz Erika), az MTA GKL (POLGÁRI Márta) és az ELTE kutatóival való rendszeres, közös alkalmazása vezetett el az első áttekintő mikromineralógiai és bauxitszedimentológiai szintézisek megalkotásához, melyek eredményeként ismeretessé váltak a Dunántúli-középhegység különböző rétegtani szintekben megjelenő bauxitjait jellemző litológiai és mikromineralógiai bélyegek (T. GECSE 1974, 1982; JuHÁSZ et al. 1986; MindsZEnTY \& GÁl Sólymos 1988; MindsZenTy et al. 

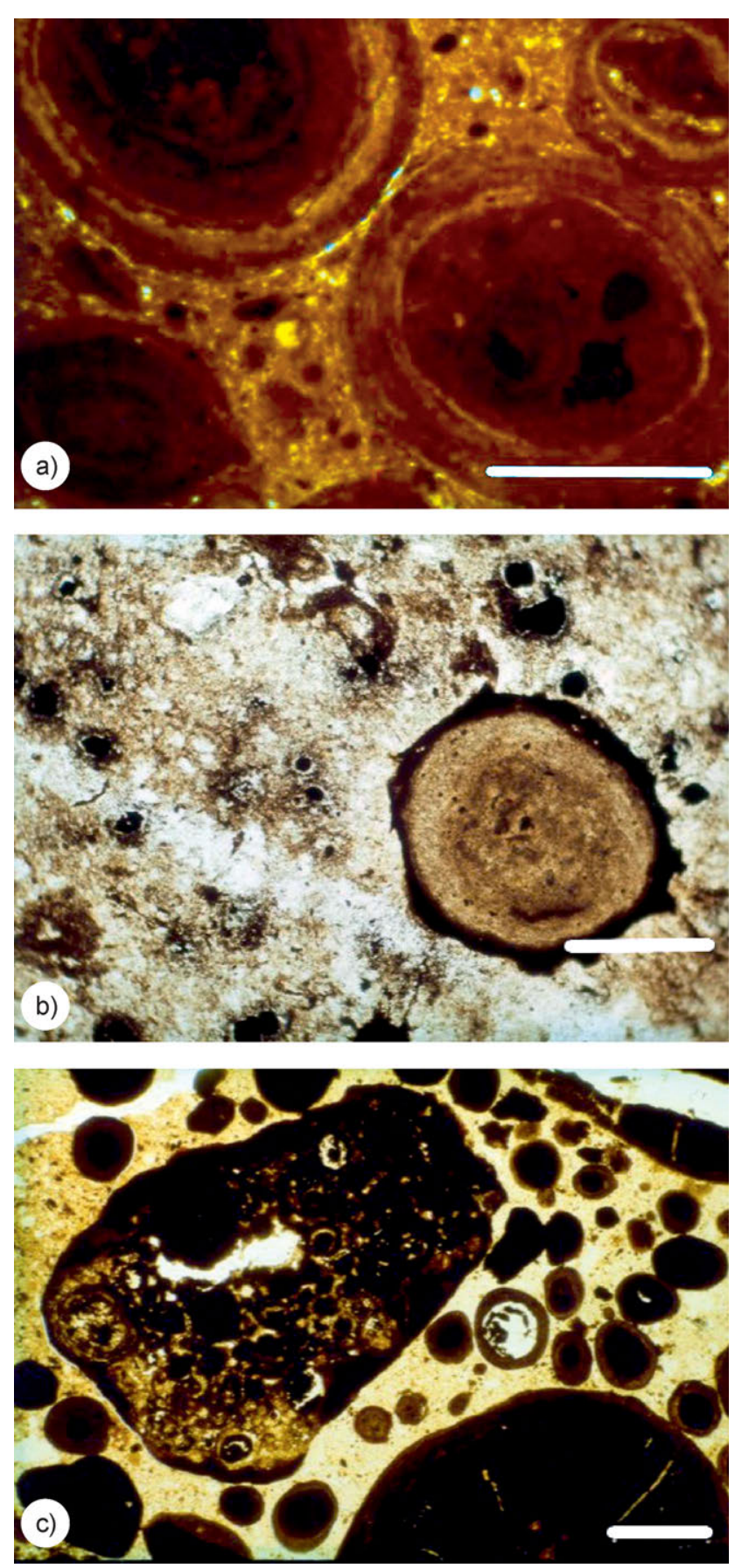

7. ábra. Fontosabb bauxitszöveti típusok mikroszkópi képe (1N, aránymérték

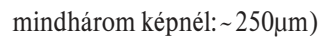

A) Pelitomorf-mikrotörmelékes alapanyagba ágyazódó akkréciós ooidok, autochtonooidos szövetủ, vadózus fáciesủ bauxitban (Iharkút)

B) A lefedődést eredményező transzgresszió miatt reduktívvá változott közegben kifakult, immár freatikus fáciesủ, kaolinites, pirites bauxit mikroszkópi képe (1N) (Nagytárkánypuszta)

C) Fakó, pelitomorf alapanyagba ágyazódó osztályozatlan gömbszemcsék és bauxitkavicsok allochton bauxitkonglomerátumban (Gánt)

Figure 7. Major lithological types of bauxites of the Transdanubian Range (plain light, scale bars all $\sim 250 \mu \mathrm{m}$ )

A) Accretional ooids embedded in pelitomorphic-microclastic matrix of a typical "vadose” bauxite (Iharkút)

B) Pale-coloured kaolinitic-pyritic bauxite formed under reducing conditions brought about by saturation of the pore-spaces on incipient transgression followed by shallow burial) (Nagytárkánypuszta)

C) Ill-sorted roundgrains and bauxite pebbles embedded in pale-coloured pelitomorphic matrix on an allochthonous bauxite-conglomerate (Gánt)
1991). Évek múltán ezek a szedimentológiai megfigyelések képezték az alapot a karsztbauxitok litofácieselméletének kidolgozásához, a vadózus és freatikus bauxitfáciesek felismeréséhez (D’ARGENio \& MindszENTY 1995, MindSZENTY 1999) (7. ábra)

A nagyegyháza-csordakút-mányi terület nagy mélységben, karsztvízszint és szenes fedő alatt, bonyolult tektonikájú környezetben települő bauxitjának szennyeződései (sziderit, pirit, Al-szulfátok) és a kitermelés várható nehézségei a tektonikai-szedimentológiai elemzések mellett a szokásosnál részletesebb, elmélyült ásványtani-geokémiai vizsgálatokat igényeltek. Az e témakörben megjelent tudományos munkák (pl. T. GECSE 1974, TóTH \& GECSE 1981, TóTH et al. 1983) nagyban hozzájárultak e különleges karsztbauxittelepek genetikájának megértéséhez. A kutatás során kiemelkedő szerep jutott VÉGH Sándornénak, az ELTE Alkalmazott Földtani Tanszéke vezetőjének és közvetlen munkatársainak (OrAVECZ János, FÁY Miklósné, HidASI János). VÉGH professzor asszony elméleti és gyakorlati ismereteire támaszkodva, a többnyire breccsás triász karbonátos feküképződmény in situ vagy áthalmozott mivoltának eldöntésében és az áthalmozott dolomit valódi természetének (fanglomerátum) felismerésében, területi elterjedésének prognosztizálásában tudtak segítséget nyújtani a Bauxitkutató Vállalat geológusainak. A terület kiemelt fontosságú része lévén az Eocén-programnak, VÉGH Sándorné 1983-ban az akkor legnagyobbnak számító kitüntetésben: Állami Díjban részesült. A tudományos és ipari megközelítésben fogant ismeretanyag nagy részét a Bauxitkutató Vállalat kutatói közössége a Veszprémi Akadémiai Bizottság kiadásában megjelent Bauxitprognózis c. könyvben (8. ábra) foglalta öszsze (SZANTNER et al. 1986).

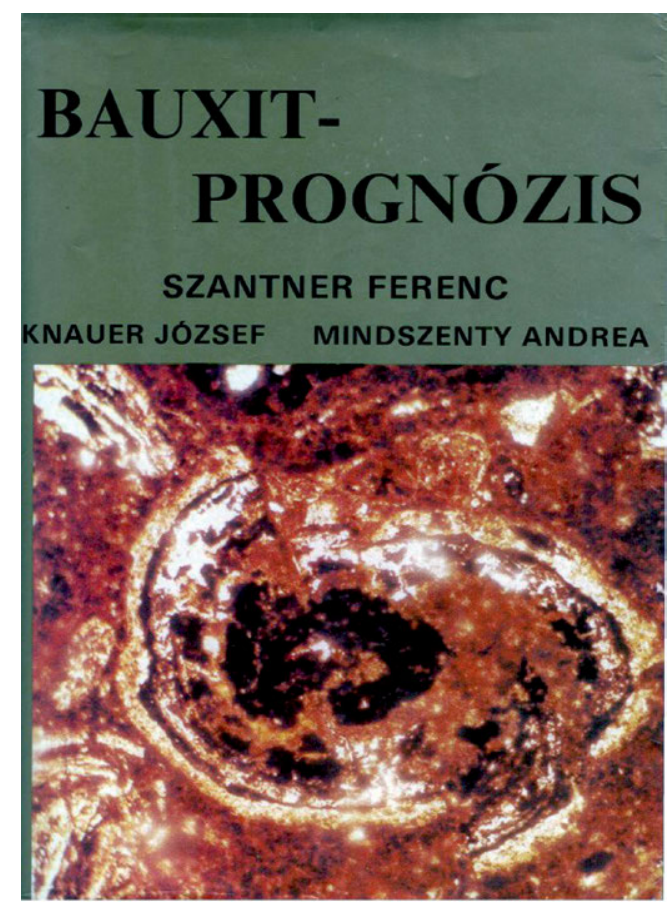

8. ábra. A Bauxitprognózis c. könyv címlapja

Figure 8. Front page of the book on Bauxite-Prognosis 
A MÁFI és a Bauxitkutató Vállalat szoros együttmúködésének fontos eredménye volt a bauxitföldtani térképsorozat megjelenése (CSÁSZÁR et al. 1978, HAAS \& JoCHÁNÉ EDELÉNYI 1978, HAAS et al. 1985), amely összefoglalását adta az ipari bauxitkutatás adatain, valamint az iparági és az intézeti geológusok egyeztetett véleményén alapuló földtani értelmezésnek, s évtizedekig jól hasznosult a geológusképzésben is.

Nemzetközi hírnevet a magyar bauxitkutatásnak és tudományos bauxitföldtannak elsősorban BÁRDOSSY György Karsztbauxitok címú (BÁRDOSSY 1977) könyve szerzett (9. ábra), melyet a világ számos nyelvére lefordítottak (1981ben oroszul, 1982-ben angolul, 1994-ben kínaiul is napvilágot látott).

A '90-es évek második felében a karsztvízszint alatti bányászkodás már említett megszúntével ismét felértékelődtek a külfejthető készletek, s így a geológia érdeklődése is megint a sekélykutatási területek (Iharkút, Németbánya) felé irányult. Ezt az érdeklődést azonban a korábbiakban megszokott, konkrét, szervezett ipari kutatási tevékenység már nem követte. A korábbiakban megkutatott németbányai lencséket (II-III.) a '90-es évek végén még letermelték. Ennek során vált ismertté, az elhivatott paleontológus Ősı Attila munkássága révén, hogy az iharkúti bauxit közvetlen fedője rendkívüli fontosságú, gazdag kréta időszaki gerinces leleteket (köztük dinoszaurusz-maradványokat) rejt (10. ábra). A tudomány szempontjából fontos és különösen pozitív fejlemény volt, hogy a leletanyag feltárásában hathatósan és segítôkészen közremúködő bányavállalat a rekultivációt a paleontológia igényeit szem előtt tartva hajtotta végre. A lelőhely így máig hozzáférhető, és évente rendszeres fosszíliagyújtő tevékenységet tesz lehetôvé. A begyújtött leletanyag tudomá

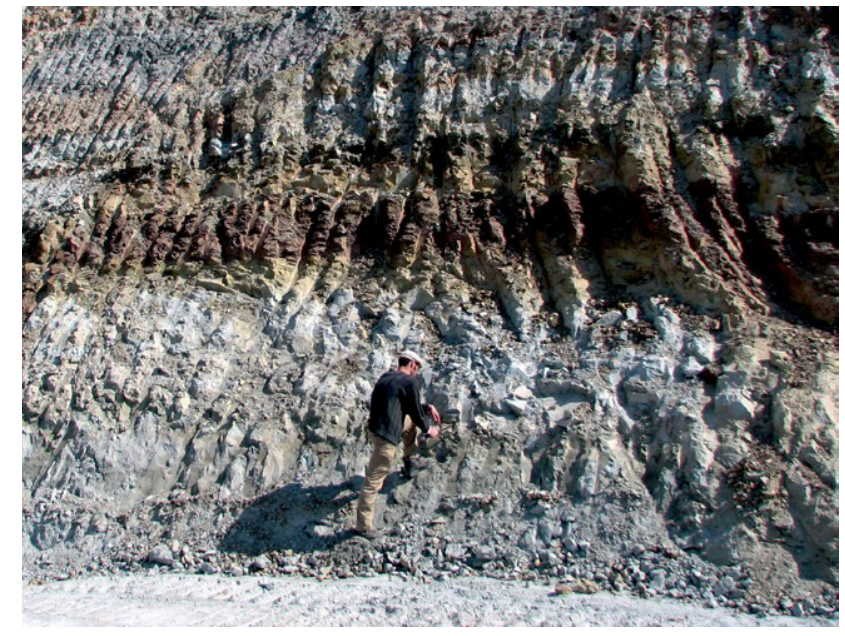

10. ábra. A dinoszauruszleleteket is tartalmazó Csehbányai Formáció paleotalaj-szintekkel tagolt ártéri kifejlődése a Németbánya II-III. lencsét feltáró külfejtés oldalfalában

Figure 10. Fine-grained overbank sediments of the Dinosaur-bearing Late Cretaceous Csehbánya Formation covering the bauxite in the open-pit of Németbánya IIIII. The dark-red bed is one of the numerous intercalated palaeosoils

nyos feldolgozásának eredményeit számos hazai és nemzetközi folyóirat és könyv ôrzi (pl. Ôsı 2005; Ôsı \& MAKÁDI 2009; Ôsi 2012; BotFALVAI et al. 2015, 2016; ÔsI et al. 2019).

Az ezredforduló után az ipari igények csökkenése felgyorsult, és miután 2013-ban a bauxitbányászat gyakorlatilag megszúnt, a további nyersanyagkutatás teljes mértékben ellehetetlenült. Érdekes módon azonban eközben a bauxitföldtan iránti tudományos érdeklődés megélénkülése volt megfigyelhető. Már 1989-1994 között - amikor pedig a re-
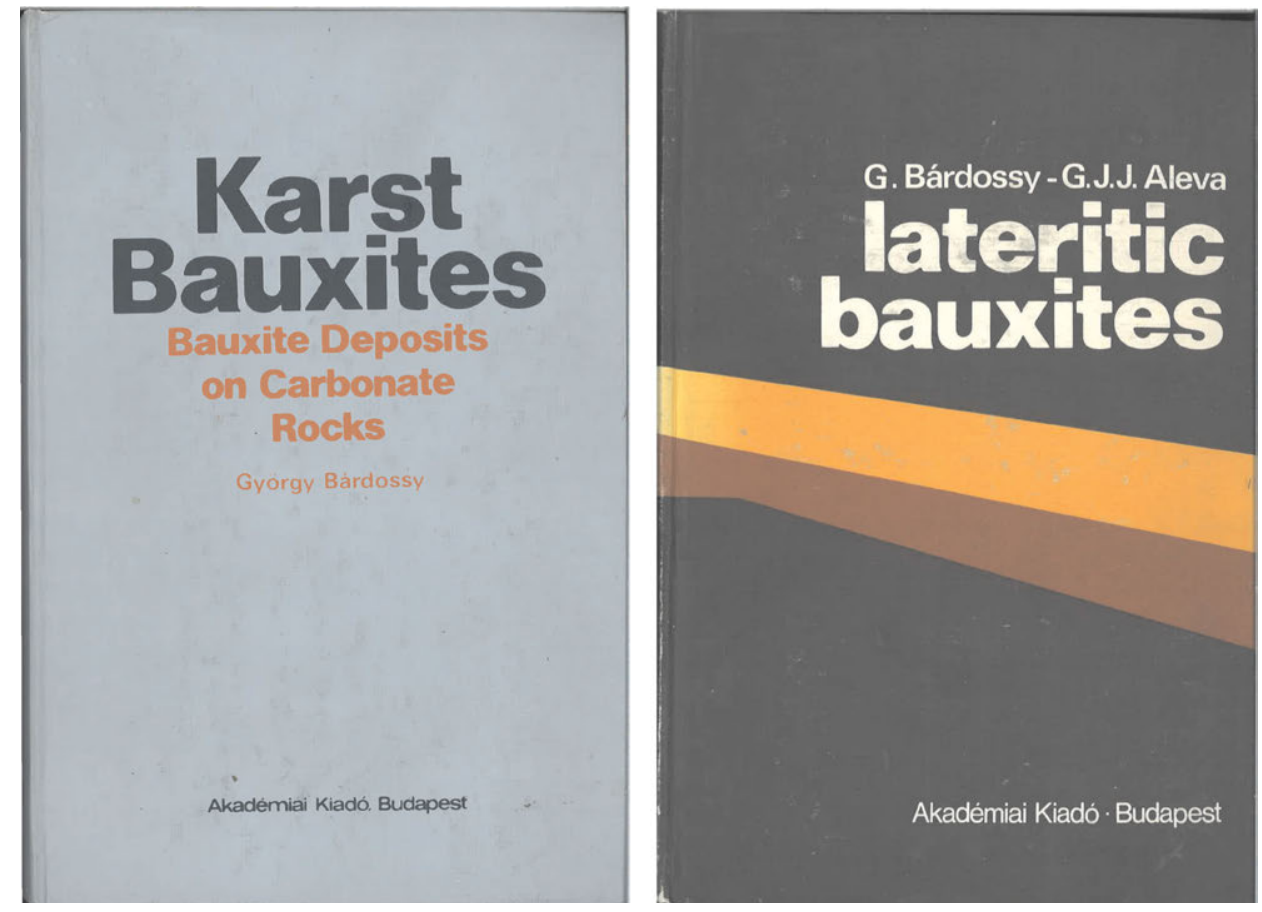

9. ábra. BÁRDOSSY Gy. és BÁRDOSSY \& ALEVA nagy sikerủ kézikönyveinek címlapjai Figure 9. Front pages of the two most popular textbooks on bauxites 
cesszió első jelei már mutatkoztak - az UNESCO és az IUGS támogatásával, nem kis mértékben az akkor az UNESCO titkárságán vezető beosztásban tevékenykedő ifj. DuDICH Endre ösztönzésére, a tethysi régió karsztbauxitjainak átfogó tanulmányozásával foglalkozó nemzetközi korrelációs projekt (IGCP-287) indult, melyben a magyar bauxitgeológia kezdeményezô és mindvégig vezető szerepet játszott. Előzménye volt ennek a vezetô szerepnek az a '80as években kezdődött (STEGena Lajos és HoRvÁth Ferenc professzorok által kezdeményezett) olasz-magyar egyetemközi együttmúködési program, amely - többek között lehetôvé tette a dunántúli-középhegységi bauxitoknak a Keleti-Alpok és Appenninek bauxitjaival való tételes összehasonlítását és az első kísérleteket a nagytektonikai értelmezésre (MindSZENTY et al. 1986, MindSZENTY \& D'ARGENIO 1987). Az IGCP-projekt résztvevői végül eredményeiket az Acta Geologica c. folyóirat 1991. évi 34. kötetének 3. és 4. számában tették közzé (HAAs, BÁRDOSSY \& MiNDSZENTY 1991). Ezt követôen felélénkült a hazai bauxitok szisztematikus szedimentológiai vizsgálata és a vizsgálati eredményeknek a TARI Gábor által felvázolt (TARI 1994) geodinamikai keretbe illesztésének kísérlete is (MINDSZENTY 1999, MindSZENTY et al. 2000). Az így kialakult képet a késóbbiekben TARI módosította és jelentősen továbbfejlesztette (TARI \& LINZER 2018).

A hazai alumíniumipar kezdődő hanyatlásával egy időben, annak eredményeire is támaszkodva született, kiemelkedő tudományos eredményként kell említenünk BÁRDOSSY Györgynek a MÁFI alkalmi kiadványaként, jelentős részben az MTA X. (Földtudományok) Osztályának anyagi támogatásával megjelent kismonográfia-sorozatát, mellyel maradandó emléket állított a hazai bauxittelepek tudományos tanulmányozásának. E kismonográfiák (Halimba, Halimba-Malomvölgy, Nyirád-K., Szőc, Iharkút) továbbfejlesztve, tudományosan értelmezve ôrzik mindazokat a geológiai adatokat, amelyek hosszú évtizedek alatt az iparági kutatás keretei közt gyưltek össze (BÁRDOSSY 2007, 2009, 2010, 2011 és BÁRdossy \& MindSZENTY 2013).

A legutóbbi, ipari adatokon alapuló, érdemi tudományos feldolgozás TóTH Kálmán és VARGA Gusztáv tollából egy olyan bauxittelepről (a diszeli bauxitról) született, amely már bányászat tárgyát nem képezhette, hiszen a 2013-as bányabezárás után került nyilvánosságra (TóTH \& VARGA 2014). Tudományos értékét jelzi, hogy a benne foglalt információra kiemelten támaszkodik egy olyan munka, amely a bauxitra már nem mint nyersanyagra, hanem mint klíma-, illetve környezetjelző képződményre koncentrál (KELEMEN et al. 2017). Ennek szerzői a Déli-Bakony bauxitkavicsokat is tartalmazó vörös agyagjának (Vöröstói Formáció) ásványos összetételét és származását tárgyalják. Egyre jelentősebb eredményeket hoz a bauxitok mikromineralógiai frakciójában jelen lévő detritális ásványszemcsék egyedi kormeghatározásán alapuló geokronológiai megközelítés, mely a bauxit kiinduló anyagát szolgáltató lepusztulási területekrôl és a bauxitfelhalmozódás tényleges koráról képes adatokkal szolgálni (DUNKL 1990, 1992; KELEMEN et al. 2017, 2020). Ezek a vizsgálatok minőségi előrelépést jelentenek a korábban a mikromineralógiai frakció ásványszemcséinek puszta azonosításán alapuló feltételezésekhez képest. Az egykori Bauxitkutató Vállalatnál felgyülemlett adattári anyagok „leletmentő” feldolgozásával az utóbbi években KNAUER József kezdett foglalkozni. 2018-ban az albai ciklus bázisán bauxitkutatás közben megismert és a Tési Formáció „Kepekői Tagozatába” sorolt, kovás-agyagos szárazföldi képződmény üledéktani sajátosságait foglalta össze, s arra a következtetésre jutott, hogy a képződmény az Alsóperei Bauxit heteropikus fáciese (GELLAI et al. 2018).

A klimatikus körülmények alakulása és a bauxittelepek globális gyakoriságának a földtörténet folyamán megfigyelhető ,„csúcsidőszakai” közötti összefüggést elemezve, BÁRDOSSY Gy. nyomdokain haladva, MINDSZENTY (2016) a bauxitos (ferrallitos) mállásnak az üvegház-periódusok idején megnyilvánuló szerepét mint visszacsatolási mechanizmust vázolja fel. Ezzel a bauxitos üledékeknek nyersanyag mivoltukon túlmutató, általános földtani jelentőségét hangsúlyozza.

Jelenleg (2020) Magyarországon egyetlen helyen, Bakonyoszlopon, a kő-hegyi bányaüzemben folyik kis volumenú (évi mintegy 40-50kt) bauxittermelés. A bánya az EOSZÉN Kft. tulajdona. A termelést FEKETE István és DióSZEGI Sándor, az egykori BBV bányageológus-mérnökei irányítják. A bányát eredetileg a bauxit fedőjében települő eocén kőszénre nyitották, de a lakossági szénigény csökkenése következtében a széntermelésról átálltak a még meglévő bauxitkészletek kitermelésére. A termelvényt kohászati adalékanyagként értékesítik.

\section{Köszönetnyilvánítás:}

A szöveg alapos és hozzáértő átnézését/javítását Dr. HAAS János és Dr. FöldESSY János porfesszoroknak, a kézirat áldozatkész gondozását és az irántam tanúsított végtelen türelmet Dr. SzTANó Orsolya főszerkesztő asszonynak köszönöm.

\section{Irodalom — References}

AlföLDI L. 2007: A Dunántúli-középhegység felszínalatti vízrendszere. 2.2. alfejezet. — In: AlföLdI L. \& KAPOLYI L. (szerk.): Bányászati karsztvízszint-süllyesztés a Dunántúli-középhegységben. MTA Földrajztudományi Intézet kiadványa Budapest, 138 p.

ALFÖLDI L. \& KAPOLYI L. (szerk.) 2007: Bányászati karsztvízszint-süllyesztés a Dunántúli-középhegységben. — MTA Földrajztudományi Intézet kiadványa Budapest, 138 p.

ALLIQUANDER E.1966: A magyar bauxitbányák múvelésének és vízvédelmének fejlődése. — Bányászati Lapok 99/9, 604-606. 
ALMÁSI I. 1993: A Gánt környéki bauxitterület szerkezetföldtani vizsgálata. — Szakdolgozat. ELTE, Alkalmazott és Környezetföldtani Tanszék, 94 p.

ANTAL, S. 1973: Micromineralogical and textural features in relation to the genesis of bauxite of Iszkaszentgyörgy. —Acta Mineralogica et Petrographica 30/1, 3-16.

BALKAY B. 1966: A magyar bauxittelepek megismerésének története és földtani sajátságai. — Bányászati Lapok 99/9, 590-603.

BALKAY, B. 1973: Bauxitization and underground drainage. - ICSOBA Travaux 9, 151-162.

BÁRDossy Gy. 1961: A magyar bauxit geokémiai vizsgálata. — A Magyar Állami Földtani Intézet alkalmi kiadványa, Budapest, 233 p.

BÁRdossy Gy. 1977: Karsztbauxitok. — Akadémiai Kiadó, Budapest, 413 p.

BÁRDossy Gy. 1997: Berthier és a bauxit kalandos története. — Földtani Közlöny 127/3-4, 483-492.

BÁRDossy Gy. 2007: A halimbai bauxit-elöfordulás. — A Magyar Állami Földtani Intézet alkalmi kiadványa, Budapest 208, 119 p.

BÁRDossy Gy. 2009: A halimbai Malom-völgy bauxit-elöfordulása. — A Magyar Állami Földtani Intézet alkalmi kiadványa, Budapest 210, $88 \mathrm{p}$.

BÁrdossy Gy. 2010: A szốci bauxit-előfordulás. — A Magyar Állami Földtani Intézet alkalmi kiadványa, Budapest, 211, 126 p.

BÁRDOSSY Gy. 2011: A nyirádi bauxit-előfordulás keleti része. — A Magyar Állami Földtani Intézet alkalmi kiadványa, Budapest, 212,117 p.

BÁRdossy Gy. \& Mindszenty A. 2013: Az iharkúti bauxit-elöfordulás. A Földtani és Geofizikai Intézet alkalmi kiadványai, 1, 133 p.

BÁRdossy Gy., DózSA L.-NÉ, GeCSE É., KeNYERES J.- NÉ \& SiKLósi L.- NÉ 1979: Bassanit és metabasaluminit a magyarországi bauxitban. - Földtani Közlöny 109, 11-129.

Bignot, G., Blondeau, A., Guernet, G., Perreau, M., Poignant, S. A., Renard, M., Riveline, J. Dudich, E., Gruas, C. \& KáZmÉr, M. 1985: Age and characteristics of the Eocene transgression at Gánt (Vértes Mts., Transdanubia, Hungary). — Acta Geologica Hungarica $28,29-48$.

Botfalvai, G., Ősi, A. \& Mindszenty, A. 2015: Taphonomic and Paleoecologic investigation of the Late Cretaceous (Santonian) Iharkút vertebrate assemblage (Bakony Mts., Northwest Hungary). — Palaeogeography, Palaeoclimatology, Palaeoecology 417, 379-405. https://doi.org/10.1016/j.palaeo.2014.09.032

Botfalvai, G., HaAs, J., Mindszenty, A. \& Ôsi, A. 2016: Facies architecture and palaeoenvironmental implications of the Upper Cretaceous (Santonian) Csehbánya Formation at the Iharkút vertebrate locality (Bakony Mts., Northwest Hungary). — Palaeogeography, Palaeoclimatology, Palaeoecology 441, 659-678. https://doi.org/10.1016/j.palaeo.2015.10.018

BöCKER T. 1965a: A nyirádi bauxitbányászat vízvédelme. — Bányászati Lapok 98/1, 25-35.

BöCKER T. 1965b: A nyirádi bauxitbányászat vízvédelme. — Bányászati Lapok 98/2, 99-117.

BöCKER T. \& HốRISZT Gy. 1992: A Dunántúli-középhegység fő-karszvízszintjének előrejelzése 1992-2010 között. — Hidrológiai Közlöny 72/5-6, 345-360.

Böcker T., Liebe P., LORBERER Á. \& SzILÁGYi G. 1986: A Dunántúli-középhegység fő-karsztvíztárolójában és a kapcsolódó vízrendszerekben bekövetkezett változások. — Földtani Kutatás 29/4, 85-90.

BöCKER, T. \& Vizy, B. 1989: Hydrogeological Problems of Hungariaqn Bauxite and Coal Deposits. — In: BosAK, P. (ed.): Paleokartst— a systematic and regional review. 533-548.

Carannante, G., Mindszenty, A., Neumann, A. C., Rasmussen, K. A., Simone, L. \& Tóth, K. 2004: Inland blue-hole-type ponds in the Mesozoic-Tertiary karst-filling seqences. - Abstracts, 15th IAS Regional Meeting, April, 1994, Ischia, Italy, 25-59.

Czabalay, L. 1983: Faunen des Senons im Bakony Gebirge und ihre Beziehungen zu den Senon-Faunen der Ostalpen und anderem Gebiete. - Zitteliana 10, 183-190.

CsÁsZÁr G., HAAS J. \& JoCháNÉ EdELÉNYI E. 1978: A Dunántúli-középhegység bauxitföldtani térképe 1:100 000. — Magyar Állami Földtani Intézet, Budapest.

CSEPREgI A. 2007: A karsztvízemelés hatása a Dunántúli-középhegység vízháztartására. — In: AlFöLDI L. \& KAPOLYI L. (szerk.): Bányászati karsztvízszintsüllyesztés a Dunántúli-középhegységben. MTA Földrajztudományi Intézet, Budapest, 77-105.

D'ARGENIO, B. \& MindsZENTY, A. 1995: Bauxites and related paleokarst, Tectonic and climatic event markers at regional unconformities. - Eclogae Geologicae Helvetiae 88/3, 453-499.

DitTLER, E. 1930: Die Bauxite der Lagerstätte von Gánt in Westungarn. — Berg- und hüttenmännisches Jahrbuch 78, 45-51.

Dudich, E. jr. \& KÁROLY, Gy. 1969: Subsurface geologic maps in Hungarian bauxite prospection. — Travaux ICSOBA, Zagreb, I., $235-249$.

Dudich E. ifj. \& Komlóssy Gy. 1969: Ősföldrajzi szempontok a magyar bauxit korkérdéséhez. — Földtani Közlöny 99/2, 155-165.

Dudich, E. jr. \& SIKLÓSI, K.-NÉ 1970: A comparative geochemical study of some major and minor elements in four bauxite deposits of Transdanubia, Hungary. - A Magyar Állami Földtani Intézet Évkönyve 54/3, 319-345.

DunKL, I. 1992: Origin of the Eocene-covered karst bauxites of the Transdanubian Central Range of Hungary: evidence from early Eocene volcanism. - European Journal of Mineralogy 4, 435-438.

Durn, G., Ottner, F., Tisljar, J., Mindszenty, A. \& Barudzija, U. 2003: Rergional Subaerial unconformities in Shallow-Marine Carbonate sequences of Istria. - Field Trip P8, 22nd IAS Meeting, Opatija, 209-254.

ERDÉLYI, M. 1965: Geological studies in the Halimba basin. — Acta Geologica Hungarica 9, 339-362.

FARKAS S.-NÉ 1992: A Dunántúli-középhegység vízföldtana és a karsztvízemelés hatása a hévízi forrásra. — Bányászati és Kohászati Lapok, Bányászat 125/1-2,7-14.

FARKAS S.-NÉ 2006: Hévíz-Nyirád története. — Bányászati és Kohászati Lapok, Bányászat 139/6, 40-44.

FAZEKAS J. 2002: A bauxitbányászat 75 éve Magyarországon. — Miskolci Egyetem Közleménye 62, 57-66.

FODOR, L. 2007: Segment linkage and the state of stress in transtensional transfer zones: Field examples from the Pannonian Basin. Geological Society Special Publications 290/1, 417-431. https://doi.org/10.1144/sp290.16

GECSE É. 1969: A Nagyegyháza-Óbarok környéki bauxit-terület ásvány-kőzettani vizsgálata. — Diplomadolgozat, ELTE Ásványtani Tanszék, kézirat. 
GECSE É. \& MindSZENTY A. 1968: Bauxit telep-szelvények ásványos összetételének mikromineralógiai vizsgálata. — In: KisS J.(szerk.): ELTE Tudományos Diákkörei, Tanulmányok a természettudományok köréból. 6-26

GEDEON T. 1932: A gánti bauxit-telep fedőrétegéről. — Földtani Közlöny 62, 95-102.

Gellai M., KNAUER J. \& Mindszenty A. 2018: Kovadúsulásos és alumíniumdúsulásos mállási és üledékképződési folyamatok a koraalbai folyamán a Csehbányai-medencében. —Földtani Közlöny 148/4,341-354. https://doi.org/10.23928/foldt.kozl.2018.148.4.341

GERMÁN-HEINS, J. 1994: Iron-rich encrustation on the footwall of the Gánt bauxite (Vértes Hills, Hungary) — evidence for presevation of organic matter under exceptional conditions. — Sedimentary Geology 94, 763-783. https://doi.org/10.1016/0037-0738(94)90147-3

GruBER Gy. \& PAPP Gy. 1969: Karsztvízszint süllyedés és vízemelés összefüggéseinek vizsgálata a nyirádi területen. — Bányászati és Kohászati Lapok, Bányászat 102/10, 678-680.

HAAS J. 1979: A felső-kréta Ugodi Mészkő Formáció a Bakonyban. — A Magyar Állami Földtani Intézet Évkönyve 61, 1-17.

HAAS J. 1988: Upper Triassic carbonate platform evolution in the Transdanubian Mid Mountains. —Acta Geologica Hungarica 31/3-4, 299-312.

HAAS J. \& JOCHÁNÉ EDELÉNYI E. 1978: A Dunántúli középhegység bauxitföldtani térképe. Felső kréta bauxitszint. — MÁFI, Budapest.

HAAS J. \& JoCHÁNÉ EDELÉNYI E. 1979: A dunántúli-középhegységi felsôkréta üledékciklus ôsföldrajzi elemzése. — A Magyar Állami Földtani Intézet Évi Jelentése 1977-ról, 217-244.

HAAs J., Tóth Á., JocháNÉ Edelényi E., KNAUER J. \& Tóth K. (szerk.) 1985: A Dunántúli-középhegység bauxitföldtani térképe. — MÁFI, Budapest.

HANTKEN M. 1861: Geológiai tanulmányok Buda és Tata között. — Mathematikai és Természettudományi Közlemények 1,213-278.

HidAsi, J. \& Mensáros, P. 1976: Electron micrprobe analysis of karstic and lateritic bauxites. Annales Universitatis Scientiarum Budapestinensis de Rolando Ë̈tvös Nominatae. Sectio geologica 18, 3-28.

HőRISZT, GY. 1971: Hydrogeology of the Nyirád bauxite region and the results of active waterprotection. — Proc. 2nd Intern. Congr. ICSOBA 2, 99-112.

JoCHÁNÉ EDELÉNYI E. 1981: A halimbai bauxit számítógépes vizsgálatának eredményei. — A Magyar Állami Földtani Intézet Évi Jelentése 1979-ról, 561-582.

JoCHÁNÉ EDELÉNYI E. 1997: A geológiai felépítés hatása a Dunántúli-középhegységi karsztvízdepressziók vissaztöltődésében. — $A$ Magyar Geológiai Szolgálat 1996. évi beszámolója, 25-27.

JochánÉ Edelényi E., Tóth Gy., SÁSDi L. \& RotáRnÉ SZALKAi Á.1996: Karsztvízföldtani vizsgálatok a Magyar Állami Földtani Intézetben. - A Magyar Állami Földtani Intézet Évi Jelentése 1996-ról, I-II., 47-151.

JuHÁsz, E. 1988: Sedimentary features of the Halimba bauxite and paleogeographic reconstruction. — Acta Geologica Hungarica 31/12, 111-136.

JuHÁSz E., Ó. KovÁCs L. 1990: A halimbai bauxit kémiai és szedimentológiai típusainak kapcsolata. — A Magyar Állami Földtani Intézet Évi Jelentése 1988-ról, I, 327-333.

JuHÁsz E. \& SZENTANDRÁSSYNÉ PolgáRi M. 1986: A mangán egyik megjelenési formája és a konkrécióképződés néhány kérdése a németbányai bauxitban. — Földtani Közlöny 116, 267-282.

KAKAS, K. PÁPA, A., SZABADVÁRY, L. \& SZANTNER, F. 1977: A geophysical prospecting proceedure for near-surface bauxite bodies. — $21 s t$ Geophys. Symp., Leipzig, Proceedings 1,

Károly Gy., Oravecz J., KopeK G. \& Dudich E. 1970: Stratigraphic horizons of the footwall and hangingwall formations of bauxite deposits in Hungary. - A Magyar Állami Földtani Intézet Évkönyve 54/3, 95-107.

Kelemen, P., Dunkl, I., Csillag, G., Mindszenty, A., von Eynatten, H. \& Józsa, S. 2017: Tracing multiple resedimentation on an isolated karst plateau: The bauxite-bearing Miocene red clay of the Southern Bakony Mountains, Hungary. — Sedimentary Geology 358, 84-96. https://doi.org/10.1016/j.sedgeo.2017.07.005

Kelemen, P., Csillag, G., Dunkl, I., Mindszenty, A., Kovács, I., von Eynatten, H. \& Józsa, S. 2020: Development of terrestrial kaolin deposits trapped in Miocene karst sinkholes on planation surface remanants (Transdanubian Range, Pannonian Basin, Hungary). Geological Magazine. https://doi.org/10.1017/S0016756820000515

KelEMEN P. et al. 2020: Paleogene ferrallitic weathering events inferred by volcanogenic zircon ages — time of formation and origin of karst bauxites in the Vértes Hills, Transdanubian Range (Hungary) (in prep.)

KESSLER H. 1954: A karsztból tartósan kiemelhető vízmennyiség és a beszivárgási százalék megállapítása. — Hidrológiai Közlöny 34/5_ 6, 213-222.

Kiss, J. 1955: Recherches sur les bauxites de la Hongrie, I. Gánt. — Acta Geologica Hungarica 3, 45-88.

KISS, J. \& VÖRÖs I. 1965: La bauxite lignitifere du Mont Bagolyhegy (Gánt) et le mechanisme de la sedimentation de la bauxite. — Annales Universitatis Scientiarum Budapestinensis de Rolando Eötvös nominatae. Sectio geologica 8, 67-90.

Knauer J. \& Gellai, M. B.1978: A szenon képződmények elrendeződése és kapcsolata az ősdomborzattal a Sümeg-Káptalanfa bauxitkutatási területen. — Földtani Közlöny 104/4, 444-475.

Komlóssy, Gy. 1967: Contribution a la connaissance de la genese des bauxites hongroises. — Acta Geologica Hungarica 11, 477-489.

KomLóssy, Gy. 1970: The Iszkaszentgyörgy bauxite (SE Bakony Mts, Hungary). Problems of genesis and mineral formation. — A Magyar Állami Földtani Intézet Évkönyve 54, 347-358.

Kорек G. 1980: A Bakony-hegység északkeleti részének eocénje. — A Magyar Állami Földtani Intézet Évkönyve 63/1, 7-176.

Kорек G. \& KeCSKемÉті T. 1965: Felsőlutéciai transzgresszió az északkeleti Bakonyban. — Földtani Közlöny 95/3, 320-327.

Kopek, G., KecskemÉTI, T. \& Dudich, E.1965: Stratigraphische Probleme des Eozäns in Transdanubischen Mittelgebirge Ungarns. — Acta Geologica Hungarica 9, 411-426.

KovÁcs J., Nemes V. \& ÖRSI A. 1976: Bauxitbányászat Fejérmegyében 1926-1976. — Fejérmegyei Bauxitbányák Vállalat kiadványa 202 p.

Maksimovic, Z., Mindszenty, A. \& PAntó, Gy. 1991: Contribution to the geochemistry of Hungarian karst bauxites and the allochthony/autochthony problem. - Acta Geologica Hungarica 34/4, 317-334. 
McKinstry, H. E. 1961: Mining Geology. — Prentice Hall, lnc, Englewood Cliff, New Jersey, US, 7th Edition, 680 p.

MindSZENTY A. 1969: Az Ujbarok-Vázsonypuszta-i bauxit-előfordulás ásvány-kőzettani és teleptani vizsgálata. — Diplomadolgozat. ELTE, Ásványtani Tanszék, kézirat.

MindSZENTY A. 1984: The lithology of some Hungarian bauxites. A contribution to the paleogeographic reconstruction. - Acta Geologica Hungarica 27/3-4, 441-455.

MindSZENTY, A. 1989: New trends in Karst Bauxite Geology. - Abstracts volume, IAS 10th Regional Meeting, Budapest, 160-161.

Mindszenty, A. 2010: Bauxite deposits of Gánt (Vértes Hills, Hungary). — IMA 2010 Field trip guide HU3, Acta Mineralogica Petrologica 11, Field Guide Series, Szeged, 1-11.

MindsZenty, A. 2016: Bauxites: Feedbacks of System Earth at Greenhouse times. — Geologia Croatica 69/1, 79-87, https://doi.org/ $10.4154 /$ gc. 2016.07

MindsZenty A. \& FodOR L. 2002: A Gánti Bauxit felhalmozódásának tektonoszedimentológiai értelmezése. — In: Hegységek és elôtereik földtani kutatása. Az MFT vándorgyúlése, Bodajk, Hungary, 27/06/2002-29/06/2002 p. 23.

MindsZENTy A. \& GÁlné Sólymos K. 1988: A halimbai bauxit extraklasztjainak földtani jelentősége. — A Magyar Állami Földtani Intézet Évi Jelentése 1986-ról, 452-467.

MindSZENTY A., KNAUER J. \& SZANTNER F. 1984: Az iharkúti bauxit üledékföldtani jellegei és felhalmozódási körülményei. — Földtani Közlöny 114/1, 19-48.

Mindszenty A., Szintai M., Tóth K., Szantner F., Nagy T., K. Gellai M. \& Baross G. 1988: Sedimentology and depositional environment of the Csabpuszta Bauxite (Paleocene/Eocene) in the South Bakony Mts. (Hungary). - Acta Geologica Hungarica 31/3-4, 339-370.

MindsZenty, A., SzŐTs, A. \& HoRváth, A.1989: Karstbauxites in the Transdanubian Mid-Mountains. — Excursion A3, Guidebook IAS, $11-48$.

Mindszenty A.; GÁl-Sólymos K.; Csordás-Tóth A.; Imre, I.; Felvári,Gy.; Ruttner A. \& Böröczky, T. 1991: Extraclasts from Cretaceous/Tertiary bauxites of the Transdanubian Central Range and the Northern Calcareous Alps. Preliminary results and tentative geological interpretation. - Jubiläumsschrift 20 Jahre Geologische Zusammenarbeit Österreich-Ungarn I, 309-345.

Mindszenty A., Csoma A., TöRöK Á., Hips K. \& Hertelendi E. 2000: Flexura-jellegú előtéri deformációhoz köthető karsztbauxit szintek a Dunántúli-középhegységben. — Földtani Közlöny 131/1-2, 107-152.

NyERGES L. \& MindSZENTY A. 1979: Bauxit teleptani jellegzetességek vizsgálata mélyfúrási, geofizikai mérésekkel és ezek jelentősége az ipari bauxitkutatásban. — Magyar Geofizika 20/5, 161-166.

Ó. KovÁCs L., JuHÁsz E. \& HuszÁr Gy. 1990: Sokváltozós matematikai módszerek alkalmazása a bauxitkutatásban. — Földtani Kutatás 33, 19-25.

OraVECZ J., VÉGHNÉ NeuBRANDT E. 1961: A Vértes- és Bakony-hegységi triász rétegtani és szerkezeti kapcsolata. — Földtani Közlöny 91, 162-169.

OtTLIK, P. \& SZABAdVÁRY, L. 1969: Geophysics on bauxites prospecting. — Proc. 2nd Intern. Symp. of ICSOBA 2, 157-168

ÔsI, A. 2005: Hungarosaurus tormai, a new ankylosaur (Dinosauria) from the Upper Cretaceous of Hungary. - Journal of Vertebrate Palaeontology 25, 370-383. https://doi.org/10.1671/0272-4634(2005)025[0370:htanad]2.0.co;2

Ösi A. 2012: Dinoszauruszok Magyarországon. — Geolitera, Szeged, 168 p.

ÔSI, A. \& MAKÁDI, L. 2009: New remains of Hungarosaurus tormai (Ankylosauria, Dinosauria) from the Upper Cretaceous of Hungary: skeletal reconstruction adn body mass estimation. — Paläontologische Zeitschrift 83, 227-245. https://doi.org/10.1007/s12542-0090017-5

Ősi, A., Botfalvai, G., Gáspár, A. \& Hajdu, Zs. 2019: The dirty dozen: taxonomical and taphonomical overview of a unique ankylosaurian (Dinosauria, Ornitischia) assemblage from the Santonian Iharkút locality (Hungary). — Palaeodiversity and Palaeoenvironments 99, 195-240. https://doi.org/10.1007/s12549-018-0362-z

PÁlfalvi, S. 2004: Paleoenvironment on a Middle Eoocene carbonate ramp in the Vértes Mts., Hungary. — Hantkeniana 4., 63-81.

PÁLFALVI S. 2007: A Vértes-hegység eocén üledékképződési környezeteinek rekonstrukciója mikrofácies-elemzés alapján. — PhD értekezés, ELTE Öslénytani Tanszék.

PAPP K. 1897: A fornai eocén medencze a Vértesben. — Földtani Közlöny 27, 417-423.

PoBOzSNy I. 1928: A Vértes hegység bauxittelepei. — Földtani Szemle 1/5, 215-252.

PoHL K.1962: Az aktív vízszintsüllyesztéssel elért eredmények. — III. Karszthidrológiai konferencia. Balatonalmádi 1962. május 2223, Bányászati Kutató Intézet kiadványa, 134-142.

PoHL K. 1966: A bányavíz-termelés jelenlegi helyzete és várható alakulása a Közép-Dunántúlon. — Hidrológiai Közlöny 46/6, 246 -254.

PoHL K. 1970: A magyar bauxitbányászat története és a felszabadulás utáni fejlődés. — Bányászati és Kohászati Lapok, Bányászat 103/6, 361-376.

PoHL, K. 1973: Procedes speciaux de prevention d'inondations souterraines et d'exploitation miniere des eaux de karst employes en Hongrie. - Travaux ICSOBA 9, Part II (Bauxite mining), 69-76, Zagreb, Yugoslavia.

PosGAY K. id. 1981: Az első magyar bauxitelőfordulás kutatástörténete és földtani-teleptani viszonyai (Királyerdő, Erdélyi-középhegység, Román SzK). — Földtani Közlöny 111, 1-25

SCHMIEDER A-WILLEMS T. 1968: A bányászattal kapcsolatos karsztvízkutatás jelenlegi állása. —MTA X. Osztály Közleményei 2/1-2,71-79.

SCHMIEDER A. \& PoHL K. 1971: Geohidrológiai kutatások eredményei a magyar szén és bauxitbányászatban. — Bányászati és Kohászati Lapok, Bányászat 104/4, 227-239.

Szabadváry L., Hoffer E., Kakas K., Nyitrai T., PÁpa A., Pintér A., Ráner G. \& Rezessy G. 1978: Komplex geofizikai kutatás a Dunántúli-középhegységben. - MÁELGI Évi Jelentése 1977-ról, 11-18.

SZÁDECZKY Gy. 1905: A Bihar-hegység alumíniumérceiről. — Földtani Közlöny 33/5, 213-231. 
SzAntNER, F. \& MindsZenty, A. 1979: Prospecting for karstic bauxites. — In: Komlóssy, GY., SzAnTNER, F. \& VöRÖS, I. (eds): UNIDO Group Training in Production of Alumina Vol 1. Principles and methods of bauxite prospecting. - ALUTERV-FKI, Budapest 201-218.

SZANTNER F. \& SZABÓ E. 1962: Új tektonikai megfigyelések az utóbbi évek bauxitkutatásai alapján. — Földtani Közlöny 92/4, 416-451.

SZANTNER, F. \& SZABó, E. 1969: The structural geological conditions and history of development of Hungarian bauxite deposits. A Magyar Állami Földtani Intézet Évkönyve 54, 109-130 pp.

SZANTNER, F., SZABÓ, E. \& KÁROLY, Gy. 1981: Latest results of bauxite geological research and prospecting in Hungary. - Proc. ICSOBA Symp, Tihany, 237-257.

SZANTNER F., KNAUER J. \& MindsZenty A.1986. Bauxitprognózis. — VEAB kiadvány, 472 p.

SZEKÉR Gy. 1975: Alumíniumiparunk és a szocialista gazdasági integráció. — Kossuth Könyvkiadó, 234 p

SzőTs E. 1956: Magyarország eocén (paleogén) képződményei. — Geologica Hungarica Series Geologica 9, 320 p.

TAEGER H. 1909: A Vérteshegység földtani viszonyai. - A Magyar Királyi Földtani Intézet Évkönyve 17, 256 p.

TARI, G. \& Linzer, H. G. 2018: Austrian versus Hungarian bauxites in an Alpine context — a tribute to prof. Andrea Mindszenty. Földtani Közlöny 148/1,35-44. https://doi.org/10.23928/foldt.kozl.2018.148.1.35

Telegdi Roth K. 1923: Paleogén képződmények elterjedése a Dunántúli-középhegység északkeleti részén. — Földtani Közlöny 53, 5-14.

TelEgdi Roth, K.1927a: Die Bauxitlager des Transdanubischen Mittelgebirges in Ungarn. — Földtani Szemle 1, 33-45.

TELEGDi Roth K. 1927b: A dunántúli bauxittelepek elterjedése és kutatása. — Bányászati és Kohászati Lapok 60, 347-351.

T. GECSE É. 1974: A nagyegyházi A/1a kutatási részterület fő bauxitszintjének és egyéb bauxitos képződményeinek vékonycsiszolatos és mikromineralógiai vizsgálata. - Kézirat, BKV Adattár (MBFSz).

T. GECSE É. 1982: A nagyegyházi bauxittelep mikromineralógiai vizsgálata. — A Magyar Állami Földtani Intézet Évi Jelentése 1980-ról, $435-448$.

Tóтн Á. \& T. GECSE É.1981: Dedolomitosodott telérszerû kőzettestek a Nagyegyházi-medence felsőtriász dolomitaljzatában. — A Magyar Állami Földtani Intézet Évi Jelentése 1979-ról, 181-200.

Tóth Á., T. GECSE É. \& PópITy J. 1983: Alunit és basaluminit a csordakúti bauxitban. — A Magyar Állami Földtani Intézet Évi Jelentése 1982-ról, 423-430.

Tóтн Á. 1985: A Gerecse-hegység délkeleti előterének eocén ősföldrajzi övezetei és kapcsolatuk a bauxittelepek elterjedésével. — $A$ Magyar Állami Földtani Intézet Évi Jelentése 1983-ról, 51-61.

То́тн K. 1981: Összefüggések a bauxit előfordulása és a közvetlen fedő eocén rétegek kifejlődése között. — Általános Földtani Szemle 14, 133-150.

Tóth K. \& VARGA G. 2014: A diszeli bauxit. — Földtani Közlöny 144/4, 483-510.

Trabelsi, K., Sames,B., Wagreich, M., Kázmér, M., Mindszenty, A. \& Martin-Closas, C. 2020: Eocene Charophytes from the bauxite-cover sequence at the Gánt section (Vértes Hills, Hungary). — Advances in taxonomy and high-resolution biostratigraphy (in prep).

VADÁsz E.1927: A magyar bauxit jelentősége. — Bányászati és Kohászati Lapok 60, 376-379.

VADÁsz E. 1930: Szénképződés, hegységképződés és bauxitkeletkezés Magyarországon. — Bányászati és Kohászati Lapok 63/10,213-224.

VADÁsz E. 1943: Alunit a magyarországi bauxitban. — Földtani Közlöny 73/1, 169-170.

VADÁsz E. 1946 A magyar bauxitelőfordulások földtani alkata. — A Magyar Állami Földtani Intézet Évkönyve 37/2, $173-286$.

VADÁsz E. 1951: Bauxitföldtan. — Akadémiai Kiadó, Budapest, 129 p.

VADÁsz E. 1966: A bauxitképződés újabb, dialektikus szemlélete. — Földtani Közlöny 96/2, 227-230.

VARGA J. (szerk.) 2020: Emlékkönyv a magyar bauxitbányászatról (A magyar bauxitbányászat története). — VARGA J. kiadása, Alphapress Nyomda, Székesfehérvár ISBN 978-615-00-7745-1, 224 p.

VATAI J. 1988: Bauxit-szöveti vizsgálatok a Gánt-bagolyhegy-i előfordulás területén. — Szakdolgozat. ELTE, Ásványtani Tanszék, kézirat.

VÉGH S.-né, FÁYNÉ TÁTRAY M., MENSÁROS P. \& BALÁSHÁZy L. 1978: A Nagyegyháza-Mányi terület kőszénfekvő képzőódményeinek és alaphegységének földtani kérdései. — Földtani Közlöny 108,7-17.

VÉGH S.-NÉ, KovÁCS J. \& MENSÁROS P. 1987: Rátolódás a Csordakút-II. bauxitlencse területén. — Földtani Közlöny 117, 93-99.

Viczián M., Dudich E. \& Tóth Á. 1985: A Dunántúli-középhegység bauxitjának ólomizotóp vizsgálata. — A Magyar Állami Földtani Intézet Évi Jelentése 1983-ról, 111-116.

VITÁLIS I. 1931: A hazai bauxitokkal kapcsolatos alumíniumvasércek. — Bányászati és Kohászati Lapok 64, 511-517.

VITÁLIS I. 1939: A magyar bauxitok és értékesítésük. — Földtani Értesító 4/2, 33-50.

Vizy B. 1999: Bauxitkutatás Magyarországon. — Magyar Alumíniumipari Múzeum kiadványa, Székesfehérvár 148 p.

VizY B. 2005: 50 év a bauxitkutatás szolgálatában. — In: HoRN J. (szerk.): Élet-Hivatás (Földtan, bányászat, energetika) — Főgeológusok visszaemlékezései. 9-38.

Vizy B. \& HőRIsZT Gy. 2005: Vízföldtani kutatások a bauxitbányászatban. — Földtani Kutatás 42/3-4, $12-14$.

VöRös I. 1958: Iszkaszentgyörgyi bauxitszelvények mikormineralógiai és nyomelem vizsgálata. — Földtani Közlöny 88/1, 48-56.

VöRÖS I. 1969: Micromineralogical investigation of the bauxite sections of Gánt, Hungary. — Proc. 2nd Intern. Congr. ICSOBA, 311-337.

VÖRÖS I. \& GECSE É. 1976: Micromineralogical and sedimentological study of some Hungarian bauxites. — Travaux ICSOBA 13, 175-183.

WeIsse, J. G. de 1948: Les bauxites de l'Europe Centrale (Province Dinarique et Hongrie). — Mémoires Société Vaudoise des Sciences Naturelles 58/9, 1-162.

Kézirat beérkezett: 2020. 09. 11. 


\section{I. tábla - Plate I.}
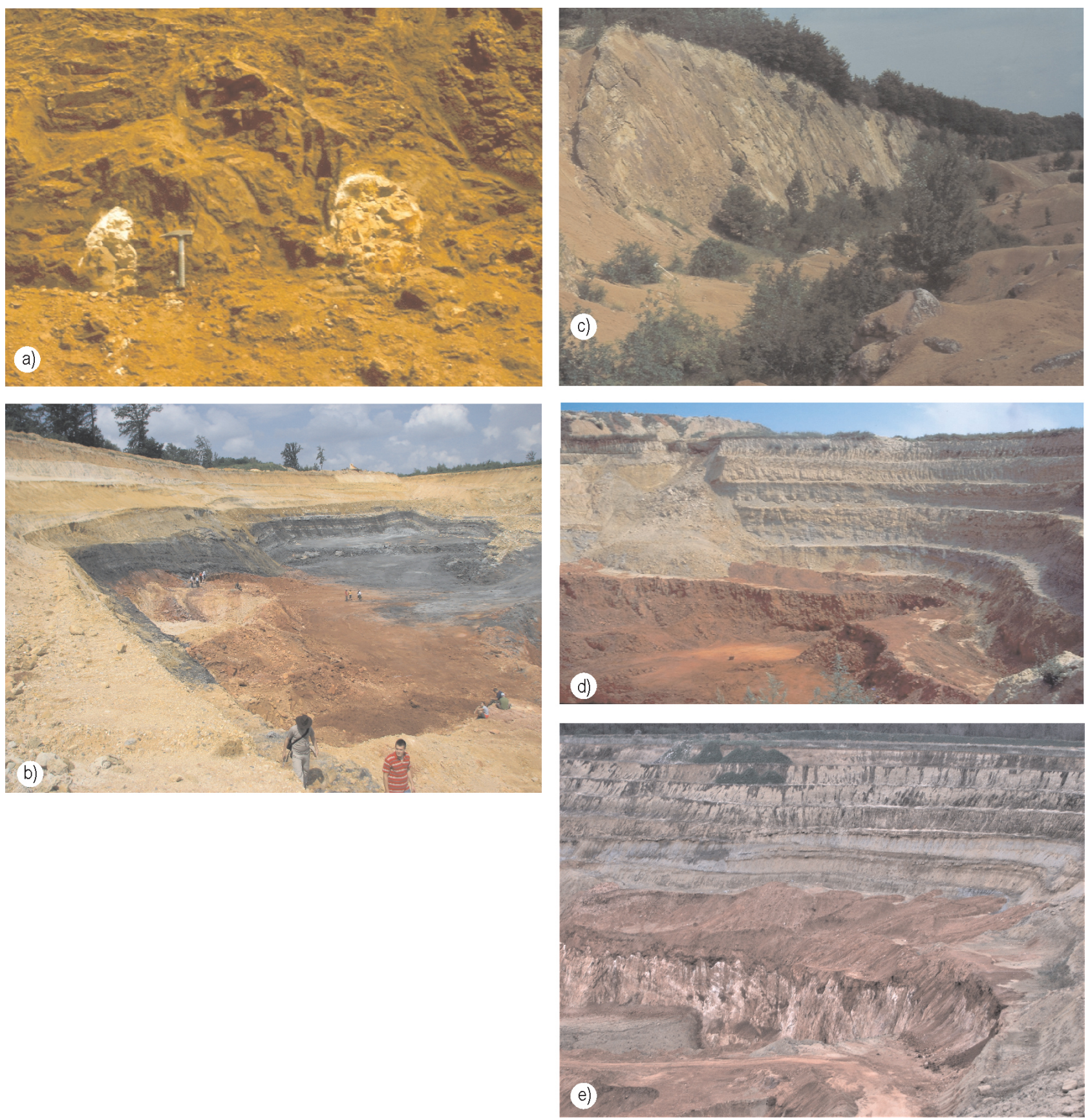

Képek egykori hazai bauxitkülfejtésekröl.

a) A Csabpusztai Bauxit alól kibukkanó Ugodi Mészkỏ anyagú karrok (Csabpuszta), b) A bauxit és a bauxitfedő Darvastói Formáció feltárása a nyirádi Táncsics-külfejtés területén, c) Az Úfeltárás K-Ny-i csapású vetőfala az előtérben, a lezökkent rögön a bauxit alól kibukkanó dolomitbörcökkel (Gánt), d) Az oligocén fedös Óbaroki Bauxitot feltáró egykori külfejtés távlati képe (2003), e) A Fődolomit karros felszinére jól látható eróziós és szögdiszkordanciával települő oligocén bauxit az Óbarok-XI. lencsét feltáró külfejtésben

Snapshots of onetime Hungarian bauxite mines.

a) Karst-pinnacles of Late Cretaceous Ugod LImestone cropping out from below the Csabpuszzta Eocene Bauxite (Csabpuszta), b) Bauxite and its immediate cover (Darvastó Formation) exposed by the Táncsics open pit (Nyirád), c) East-West striking major fault in the Úffeltárás open-pit (Gánt). In front, on the downthrown block some karstic cliffs of the bedrock crop out from below the bauxite, d) Panoramic view of one of the open-pits exposing the Oligocene bauxite of Óbarok, e) Serrate karst surface developed on Triassic dolomite, overlain by Oligocene bauxite in the ÓbarokXI open-pit, Note the obvious erosional and angular unconfomity between bauxite and its bedrock. 